POLEMIKA

\title{
O JEZIKU I NOMOTEHNICI NACRTA ZAKONIKA O SVOJINI I DRUGIM STVARNIM PRAVIMA
}

\section{Povodom istoimenog teksta Luke Breneselovića ${ }^{1}$}

\section{IPAK, NIJE BAŠ SVE PROPALO}

1. Breneselovićeva je uznemirenost velika. I ne bila. Jer: „kada se u tekstu koji će morati da čitaju milioni čitalaca grubo ne poštuju“ stilska pravila, „kao u slučaju našeg Nacrta Zakonika o svojini i drugim stvarnim pravima, onda se može govoriti o propasti dobrog jezičkog - pravnog - izraza“ (str. 183). I ne bio uznemiren kada je našao da je taj koncentrat pokvarenog jezičkog pravnog izraza još i sunovrat nomotehnike: „Osim po broju slova sitnih, ali po dometu krupnih stilskih pa i gramatičkih pogrešaka koje se sreću u gotovo svakoj odredbi, Nacrt Zakonika o svojini i drugim stvarnim pravima i inače odlikuje neobična nomotehnika“ (str. 194). Gde god da se zagrebe, u koji god član Nacrta da se dirne, pokaže se da on „u celini boluje“ od „temeljnih nomotehničkih nedostataka“, „indikativnih ... za nomotehniku celog Nacrta“ (str. 195).

Nije Breneselović samo oglasio uzbunu. On je i spasilac. Onaj koji zna put. Kojim će nas izvesti iz jezičkih, stilskih i nomotehničkih bespuća u koje odvedoše tvorci Nacrta. Nesmotreno je, međutim, poći za bilo kim ko nudi spasenje, ne sagledavši prethodno ne samo njegov plan spasenja (o njemu pod III), nego, što je manji posao, pa će prvo biti obavljen (II), njegovu sopstvenu jezičku, stilsku i nomotehničku praktiku. Nalaz zbunjuje: nije li možda posredi plemenito samožrtvovanje i samozatajenje kada se neko trudi oko tuđeg jezika, stila i nomotehnike, a zapusti svoje?

2. Zajedljiva bi bila primedba da se jezikom u pravu, stilom ili nomotehnikom bave oni koji o pravu samom nemaju šta da kažu. Bila bi i neopravdana. Jer, tako često je bavljenje jednim neodvojivo od bavljenja drugim, pošto su jezik, stil ili nomotehnika neretko nerazdvojivi od sadržine prava. Ali, baš zato valja obratiti pažnju na to da li se nečija briga za dobrobit pravničkog

\footnotetext{
* Redovni profesor Pravnog fakulteta Univerziteta Union u Beogradu

1 U ovom broju, str. 183-213.
} 
jezika, stila ili nomotehnike ne hrani njegovim neodrživim materijalnim, sadržinskim pravnim stavovima. Kao i obrnuto, da li nečije jezičke, stilske i nomotehničke opaske ne povlače za sobom neodrživa sadržinska rešenja pravnih pitanja. Bez obzira na to što Breneselović (na str. 208) kaže da „o sadržaju ovde nije rečc, on na oba opisana načina napušta teren samog jezika, stila ili nomotehnike, i i te kako se opredeljuje o sadržinskoj, materijalnoj strani stvari. Pošto je uloga normativnog teksta da bude pravilo ponašanja, to su i za Nacrt najvǎnija materijalna stvarnopravna rešenja. A kod Breneselovića ima neodrživih stvarnopravnih stavova, nekih kao posledica njegovih jezičkih, stilskih i nomotehničkih postavki, nekih kao uzrok njegovih jezičkih, stilskih i nomotehničkih predloga.

3. Nijedna zamerka koja će biti upućena Breneseloviću ne umanjuje, naravno, korist od njegovih opravdanih opaski o Nacrtu, na kojima mu hvala. Samo što ove poslednje, koje je on uputio Nacrtu, nisu razlog da one prve, koje povodom Nacrta mogu biti upućene njemu, ne budu sa zasluženom pažnjom izrečene.

\section{JEZIČKA, STILSKA I NOMOTEHNIČKA NEBRIGA BRIŽNOG ZA JEZIK, STIL I NOMOTEHNIKU}

1. Skerlić reče: Ne moram biti kokoška, da bih znao da je nešto mućak. Parafrazirano, iako nisam kokoška - čitaj: dobar znalac lingvistike, stilistike ili nomotehnike kao nauke, znam da u Breneselovićevom tekstu ima jezičkih, stilističkih i nomotehničkih - mućkova. A, onaj ko drugome preporučuje brigu za jezik, stil i nomotehniku, i sam bi morao o njima da brine. Ko istupa kao znalac dobrog jezika, stila i nomotehnike, ni sam ne bi smeo da ih ne poznaje odnosno ne uvažava.

Od nekog takvog ne očekuje se, recimo, da umesto „a da“ kaže „bez da“ (kao Breneselović na str. 187). Niti da pomoću „bez da“ hoće jezički da poboljša formulaciju neke odredbe (kao na str. 187. u vezi sa članom 104). „Bez da" u srpskom jeziku naprosto ne može (osim kao poruga crnogorskom neknjiževnom načinu). - Ne očekuje se od takvoga ni da u njegovom tekstu bilo šta „proizilazi“ iz bilo čega (kao na str. 203). Jer je sigurno da ni sam Breneselović za sebe ne kaže, primerice, da upravo „izilazi“ iz stana, nego da izlazi. - Ali se, naprotiv, s osnovom očekuje od takvog znalca i lovca na tuđe greške da zna da „utoliko ako“ (str. 183) jednostavno ne ide, pošto utoliko traži ukoliko, i obrnuto (tzv. komplementarna ili binarna frazeologija). - Takvome nije preteran zahtev ni da povede računa o tome da kada kaže da se nešto može "podjednako izraziti“ (i glagolom i imeničkom ili pridevskom konstrukcijom, i da tada prednost zaslužuje konstrukcija sa glagolom) (str. 183), to nije drugo do opet jedna (logička i) stilska nespretnost. „Podjednako izražavanje“ ne predstavlja određenje već po sebi: „podjednako izražavanje“ može, naime, po- 
djednako da bude podjednako dobro izražavanje kao i podjednako loše izražavanje. - Nema nikakvog opravdanja da neko takav upotrebljava reči (kao na str. 188) koje nisu u stanju da ponesu značenje koje bi da im da: morao bi da razlikuje „upitnu“ rečenicu, a što je jedna vrsta rečenice, od problematičnosti rečenice, a što je valjda hteo da kaže pogrešno pominjući upitnu rečenicu. Ni konferencijski jezik („odsustvo poverenja“, str. 196) nije na diku nekome toliko brižnom za jezik: kod njega je, međutim, i poverenje u stanju da bude prisutno ili odsutno. - Kod Breneselovića je Zakonik „,citav“ (str. 197), „čitav“ je i Nacrt (str. 196), a takav je i član (str. 184, 197), a ne ceo, kakav je kod onih koji vode računa o jeziku.

Član nije „jedan“ nego je prvi, nije „sedamdeset dva“, nego je sedamdeset drugi. Nijedan član u propisu nije jedan, nego je prvi jer je prvi u nizu članova, nije sedamdeset dva, nego je sedamdeset drugi u nizu. Zato ne može, kako je kod Breneselovića bez izuzetka u celom tekstu: „član 1“, nego mora: član 1., ne: „član 72“, nego: član 72., i sve tako. I nedavno doneta Jedinstvena metodološka pravila za izradu propisa, ${ }^{2}$ propisuju (članom 24. stav 2): „Član se označava rečju član’ sa odgovarajućim arapskim brojem iza kojeg se stavlja tačka, počevši od broja jedan, a zatim po redosledu brojevima do poslednjeg člana u propisu (npr.: Član 1.)“. Iz istog razloga ni stav ne može da bude stav dva ili jedan („u stavu dva tog člana“, str. 185, „,iz stava jedan ovog člana“, str. 187, „iz stava 1“, str. 188). - Duga je tradicija, poštovana dosledno u Nacrtu, na kojoj istrajavaju i Jedinstvena pravila (član 25. stav 2), da stav člana sadrži samo jednu rečenicu, a dve ili više jedino onda kada je to potrebno radi razumljivosti. Breneselović ignoriše takvu tradiciju (na str. 184. i 188. formuliše član 4. stav 1 , odnosno član 655. st. 2. i 3. tako što po dve zasebne rečenice tvore jedan stav), dok u Nacrtu tako što nigde ne biva. - U propisima se upotrebljava jednina, a to sada i izričito traže pomenuta Jedinstvena pravila (član 42). U tekst Nacrta, koji se toga već ranije dosledno držao, Breneselović bi, bez ikakvog opravdanja, unosio odredbe izražene u množini („Stranim fizičkim licima“, „iseljenici“, „potomci“, član 31. stav 3, str. 190, „(Pravni) položaj životinja“, „Položaj kućnih ljubimaca“, naslov člana 18, str. 196, „Zadržavanje dužnikovih stvari“, naslov člana 522, str. 205, „Sticanje pokretnih stvari“, naslov člana 87, str. 205). - Propisi se izražavaju u sadašnjem vremenu, što sada potvrđuju i Jedinstvena pravila (član 41). U tome je Nacrt bio dosledan, dok bi Breneselović to narušavao budućim vremenom glagola $\mathrm{u}$ pojedinim odredbama („smatraće se“, član 9, str. 187).

2. Ko drugome štogod zamera, sam ne bi smeo da se izloži istim zamerkama. Ipak, baš kada se radi o onome što preporučuje kao poboljšanja Nacrta, njegov tekst je podložan brojnim istovrsnim zamerkama. Evo i ovakvim.

Preporučuje: ako može sa manje reči, tako bi i trebalo kad god su neke reči višak (str. 186). I zamera da je „Sasvim ... nejasno zbog čega su pisci Nacr-

2 „Službeni glasnik RS“, br. 21/10. 
ta“ (u članu 4. stav 2) „podvukli da je reč o ugovoru strana (drugačije ne može ni biti)“. Ko bi mu protivslovio? Ali sam gomila nepotrebne reči. Recimo, u formulaciji koju nudi (na str. 188) za član 655. stav 1. o zadržavanju svojine: „(1) Prodavac i kupac pokretne stvari mogu se dogovoriti da prodavac i posle predaje stvari ostane njen vlasnik, a sve dok kupac u celosti ne isplati cenu koju je sa prodavcem ugovorio." Čemu reči: „koju je sa prodavcem ugovorio“? A s kim bi drugim? - Nije drugo do višak ni kada zahteva da se u članu 114. „rok od jedne godine“ zameni sa „rok od godinu dana" kako se na „našem jeziku, osim izuzetno, kaže“ (str. 192). Bez obzira na taj njegov jezik, i u našem pravnom jeziku se godina sastoji od dana. Tako da niko neće pomisliti da je to rok od jedne godine krušaka, jedne godine dece ili sl. Usvojiti „rok od godinu dana" vodilo bi i u dalje viškove: kada se radi o roku od više od jedne godine, odredbe bi morale glasiti, na primer kod održaja: „rok od tri godine dana“, „od dvadeset godina dana“. Nacrt ipak nije narodna pesma. - Drugima cepidlači i zbog jedne suvišne reči, a rasipa se brojnim. Zašto (u svojoj varijanti člana 104, na str. 188) rastrošno kaže: stvar prodao „po uslovima povoljnijim od onih koje je u obaveštenju istakao", umesto samo: po uslovima povoljnijim od onih iz obaveštenja. („Istakao" uslove je, k tome, i zbunjujuće - zar nije dovoljno da ih je naveo, mora li ih i podvući, naglasiti?). - Jednoj odredbi Nacrta (član 9. stav 1) zamera nepreciznost: da to na šta se odnosi jedan njen deo „proističe iz pravničkog rezonovanja, koje u datoj rečenici nije precizno jezički zabeleženo" (str. 187). Da nije baš tako, videće se kasnije (III.b.3). Ali se baš taj tip nepreciznosti omakao njemu samom. Pretendujući na to da je time poboljšao odredbu člana 4. stav 1 . Nacrta, ovako ju je preinačio (na str. 184): „Nosioci stvarnih prava i organi koji zakon primenjuju ne mogu izmeniti osnovni sadržaj stvarnih prava, već ih samo mogu bliže odrediti. Isto važi i za ugovore“. Pošto je prva rečenica adresovana na subjekte, a druga na ugovor, onda tek „pravničkim rezonovanjem“ dolazimo na čisto u pogledu toga na šta to iz prve rečenice se odnosi „isto važi“ iz druge rečenice: da li subjekti iz prve rečenice (nosioci stvarnih prava i organi primene zakona) ne smeju izmeniti ni ugovor, kao što (kako u toj rečenici piše) ne smeju izmeniti osnovnu sadržinu stvarnih prava, ili se pak osnovna sadržina stvarnih prava ne sme izmeniti ni ugovorom. Međutim, što u tom drugom slučaju ograničenje važi, ničim opravdano, samo za ugovor, a ne, kako bi trebalo, i za bilo koji drugi pravni posao, e to je već više nego tek puka nepreciznost. - Traži pažnju od tvoraca Nacrta, a sam se zbog nepažljivog čitanja izlaže tome da mu se osnovano prebaci da čitaoca opterećuje čak i izlišnim primedbama. Ispravno kaže da se „zamenica u jednini ('njene') ne može upotrebiti za označavanje alternativno određenog pojma ('stvar ili hartija od vrednosti') tako da označi obe alternative. Ne može se reći šolja i čaša duguju njenu čistoću domaćici' i ne može se reći da poverilac koji drži stvar ili hartiju od vrednosti može da se namiri iz 'njene vrednosti' (str. 196). Lepo, ako bismo govorili apstraktno. Ali se konkretno u članu 522. stav 1. Nacrta reč „njene“ i ne odnosi na obe 
alternative, zajedno, već se alternativno odnosi samo na jedno ili samo na drugo: odnosi se na stvar ili na hartiju od vrednosti, zato što između „stvar“ i „hartiju od vrednosti“ stoji „odnosno“ („dužnikovu stvar, odnosno hartiju od vrednosti") a ne ili, kako je pročitao Breneselović. Zna se da (ni) u propisima „ili“" i „odnosno“ nisu u svakoj upotrebi isto. - On lepo i ubedljivo zbori o tome da li, i gde (da li u didaktičkim delima, udžbenicima, naučnim radovima itd.) važi pravilo da za označavanje iste pojave treba stalno upotrebljavati istu reč. Za naučnu prozu kaže da u njoj promena termina za označavanje istog kompleksnog pojma može navesti čitaoca da pomisli da on tada izražava drugi pojam (str. 210). Nije, doduše, ta razmatranja doveo ni na koji način u vezu sa normativnim tekstovima, pa ni sa Nacrtom (tako da ta izlaganja u napisu o Nacrtu zalud traže svoju tačku vezivanja). Pošto normativni tekst izražava pravila ponašanja, kojih bi adresati trebalo da se drže, to opasnost dezorijentacije u slučaju upotrebe raznovrsnih termina nalaže još veću postojanost terminologije nego u naučnoj prozi. Međutim, izgleda da Breneselović jedino sebe nije ubedio u valjanost preporuke o postojanoj upotrebi iste reči. Jer, dok na jednom mestu normativnog teksta koji predlaže upotrebljava reč „položaj“ (str. 194), na drugom, upodobljivom mestu kaže, međutim, „status“ (str. 192). Uzgred, čemu tuđice ako nam ne manjka naše? - Kome je do toga da tuđ tekst bude stilski harmoničan, ni sebi ne bi smeo da dopusti ekscesne disharmonije. Breneseloviću je draga reč „lasno“. Kod njega je „izražavanje lasno“ - „nauka o lasnom izražavanju“ (str. 183); kod njega je „razumevanje lasno“ - „na štetu lasnog razumevanja“ (str. 193); kod njega se „ideja lasno hvata“ - svako (na str. 202) „može lasno da uhvati osnovnu ideju“. (Na stranu da li je ideja nešto što se hvata?). Njemu, kome je toliko do lakoće razumevanja i do razumljivosti svakome (str. 183, 184, 185, 186, 188, 193, 196, 197, 201, 202, 205, 210), ne smeta što je u Srbiji malo ljudi koji znaju o čemu se tu radi kada kaže „lasno“, i tek im kontekst to kaže. A biće ih sve manje. „Milioni čitalaca“ (to Breneseloviću drago preterivanje, videti str. 183) koji će čitati njegov tekst, teško da će „lasno“ dokonati šta je „lasno“. Stilski, pak, taj arhaizam u njegovom tekstu štrči; jedini je - drugih arhaizama nema. Pa se pitamo zašto nema i drugih izobičajenih reči, kada ih ne manjka inače u rečnicima. Uzmimo samo Daničićev, kao riznicu odumrlih srpskih reči, posebno za apstraktne pojmove. (Jedna uzgredna napomena: „lako“ je odnedavna ugroženo s još jedne strane, u većim razmerama nego kod Breneselovića. Svedoci smo da je u modi, posebno u televizijskom govoru, da se „lako“ zamenjuje sa „lagano“: lagano je dobio ovaj gem, lagano je pobedio, lagano su otkrili i sl. Što bi i u pravničkom izražavanju bilo podjednako neprimereno: lagano dokazati, lagano ukinuti odluku, lagano se odreći prava, lagano razrešiti sudiju, lagano otpustiti zaposlenog.)

3. Breneselović bi trebalo prvo da se izbori za to da neki njegov stav postane važeći, i to među jezičarima, pa tek onda da ga propoveda i nama, pravnicima. 
On tvrdi, tako, da u članu 167. čitamo „podrazumeva, iako bi“, kaže, "moralo stajati razume“ (str. 190). Odakle mu to, kad su obe mogućnosti ravnopravne? - Kazaće (na str. 192) da se u članu 195. govori o naknadi troškova učinjenih radi zadovoljstva, „iako se troškovi ne čine, već prave ili prosto imaju“. Između činiti i praviti razlika je zanemarljiva, a u gruboj nesrazmeri sa Breneselovićevim rigorizmom koji bi da na njoj izgradi. (A jezik u zapadnoj varijanti ima i oblike "graditi“ $i$ „raditi“ troškove.) -Nepomirljivo pridikuje o redu reči: „Iako je red reči u našem jeziku načelno slobodan, ljudi sa osećajem za jezik ne biraju svaki red reči i po pravilu i određene padežne oblike upotrebljavaju samo na kraju, u sredini i na početku rečenice iako ih je formalno moguće upotrebiti u bilo kom delu rečenice" (str. 193). Ali pridikuje bez podrške u brojnim studijama napisanim i ovde i u inostranstvu o redu reči, toj toliko važnoj stvari u lingvistici sintakse. (Potencijalno važnoj i u životu; setiti se - ibis redibis nunquam peribis in bello.) Te studije ne (pre)poručuju, poput Breneselovića, ni da se padeži izbegavaju, ni da se favorizuju. Njihova upotreba nije regulisana ni ideološki, ni estetički. Misao koja se rečenicom izražava neće biti jasnija ako se izrazi akuzativom umesto dativom ili nominativom. Uvek je u pitanju svrsishodnost upotrebe jezičkih sredstava. - Tako su neuhvatljivi ti Breneselovićevi svedoci: „najpažljiviji čitaoci“" (sa str. 193-194. i 205) i "ljudi sa osećajem za jezik“ (sa str. 193). Te himere koje on postavlja za žrece u stvarima jezičkog osećaja i reda reči. Mojoj predstavi o "ljudima sa osećajem za jezik“ nikako ne odgovara Breneselovićev osećaj za red reči. Na primer, on kaže „Pisci Nacrta nisu samo loše upotrebljavali veznike, već i druge reči“ (str. 190). A, „ljudi sa osećajem za jezik“, kako ih ja čujem, rekli bi: Pisci zakona nisu loše upotrebljavali samo veznike, već i druge reči. Takođe bi oni rekli: Lice upisano kao imalac stvarnog prava u javnom registru, smatra se imaocem tog prava „dok se ne dokaže suprotno", a ne kao Breneselović (na str. 187, nudeći poboljšanje formulacije člana 9. stav 1), „osim ako se suprotno ne dokaže“. Ne bi ti ljudi sa osećajem za jezik išli za ovakvim Breneselovićevim rasporedom reči: „Ako je prodavac stvar prodao trećem licu, bez da je lica koja imaju pravo preče kupovine o prodaji uredno obavestio", nego bi ih preraspodelili ovako: a da nije o prodaji uredno obavestio lica koja imaju pravo preče kupovine (str. 188). I ne (kako je na istom mestu): „i njega kao pravog kupca naznači“, već: i naznači ga kao pravog kupca. (Uzgred, onaj ko je kupio, doista je pravi kupac, a ne, kako bi Breneselović, da je „pravi kupac“ onaj ko nije kupio jer mu nije ni ponuđeno. Uostalom, pravi kupac traži nepravog, a takvog ovde nema.) Jednako tako ne bi ovako složili reči (na str. 194): on mora da bude u tematskoj sprezi sa tekstom koji označava i - podređen čitaocu, ,a ne piščevom toku misli i logici celine koju pisac uvek u glavi ima", već ovako: a ne toku piščevih misli. Ne bi ga pohvalili ni za ovaj red reči: „Savesni držalac ima pravo na naknadu sredstava koje je u stvar za svoj [slatki] užitak uložio“ (str. 192), nego bi preporučili: Savesni držalac ima pravo na naknadu sredstava koja je uložio u stvar za 
svoj [slatki] užitak“. Baš je nespretno rasporedio reči u rečenici: „Pravo svojine se ili može odrediti kao najšire pravo da se postupa sa stvari ili pak kao pravo da se po sopstvenom nahođenju postupa sa stvari, ali je besmisleno reći da je to najšire pravo da se po sopstvenom nahođenju postupa sa stvari“ (str. 198), jer bi glatko tekla da je glasila: Pravo svojine se može odrediti ili kao najšire pravo ... ili pak kao pravo ... Breneselović, kada se dohvati druge teme, kao da zaboravlja šta je u drugoj prilici sam preporučivao.

4. U nekim slučajevima čitalac mora da se doista svojski napregne, baš napne da bi u Nacrtu otkrio problem koji se Breneseloviću čini tako veliki i upadljiv. Opet, posve ostaje tajna zašto bi, odnosno zašto je u Nacrtu učinio neke druge izmene. (Nikako nije lepo menjati tuđe bez ikakvog obrazloženja.)

Niko Breneseloviću ne brani da misli (na str. 184) da je ikakvo poboljšanje njegova formulacija: „sadržaj stvarnih prava ne mogu izmeniti organi koji zakon primenjuju“, u poređenju sa onom iz člana 4. Nacrta: „sadržinu stvarnih prava ne mogu izmeniti organi primene zakona“. „Prirodan i neposredan nemir“ koji pripisuje drugim čitaocima u susretu sa formulacijom iz Nacrta, samo je njegova uobrazilja. Zato ni njegovi „organi koji primenjuju zakon“ umesto „organa primene zakona“ iz Nacrta, nemaju kod čitalaca nikakvo umirujuće blagotvorno dejstvo. Ali, zašto ne verovati da on takav nemir doista tanano detektuje kod sebe? Nije jasno jedino, čemu ga čini javnim. - Reči koje dobro idu uz prostorne i vremenske predstave (uhvatiti miša, uhvatiti kamen, uhvatiti se za glavu), Breneselović olako prenosi i na one nematerijalne (već smo se sreli sa „hvatanjem ideje“, str. 202). I kada se radi o pravu i pravnim pojavama koje su, zna se, nematerijalne, on takvim rečima daje prednost pred izrazima koji su primereniji za nematerijalno: „nosilac [subjektivnog] prava“ je njegov favorit umesto: imalac prava (str. 209), pa je i iz normativnih odredaba proterao imaoca da bi uselio nosioca (član 4. stav 1, str. 184). Nosilac još i više nego imalac upućuje na prostorno, asocira na fizičko (nosilac kamena), dok je subjektivno pravo, o čijem se nosiocu radi, jedna nefizička, duhovna pojava. Klimav je (kako Breneselović voli da kaže, str. 189, 193) taj prenos onoga što odgovara materijalnom na nematerijalno. Kao što niko još nije seo na pravo, šutnuo ga, bacio i sl., tako ne može ni da ga nosi. A imati se mogu i nefizičke pojave, kao što se ima ideja, ugled, ukus itd., pa i pravo. ${ }^{3}$ - Sadržaj i sadržina nisu baš isto - kao što se sadržajno i sadržinski ne podudaraju (predavanje je bilo sadržajno, ali ne i sadržinsko). Breneselović je, međutim, svuda, pa i u tekstu Nacrta, sadržinu svuda zamenio sadržajem (član 4. str. 184. i 185), nigde ne obelodanivši motive.

3 O mišljenju u prostornim i vremenskim predstavama u pravu, up. Werner Rother, Elemente und Grenzen des zivilrechtlichen Denkens, Berlin 1975, str. 12. i d. 


\section{NAVODNE GREŠKE NACRTA - STVARNE GREŠKE KRITIČARA: NEPRIHVATLJIVA PRAVNA REŠENJA}

Od nekoga ko bi da popravlja jezik, stil i nomotehniku zakona, ne očekuje se da zakon pri tome suštinski (sadržinski, materijalno) kvari. A ni obrnuto, da suštinskim (sadržinskim, materijalnim) rešenjima kvari jezik, stil ili nomotehniku. Niti da pogreškama u pravnim stavovima i o pravnim stavovima proizvodi neprihvatljiva pravna rešenja. Evo od svega toga.

\section{a. NUMERUS CLAUSUS}

1. FANTOM NEDOSTAJUĆEG (1). Dok član 4. Nacrta ne dopušta da imaoci, stranke i organi primene prava izmene „sadržinu stvarnih prava, određenu zakonom“, Breneselović bi bio šire ruke: da oni ne mogu izmeniti samo „osnovni sadržaj stvarnih prava“ (str. 184).

Nije svejedno. Taj aspekt principa numerus clausus stvarnih prava, da se sadržina stvarnih prava određuje kogentnim normama, ne trpi arbitrernost koju podrazumeva ničim određeno razlikovanje između osnovne i neosnovne sadržine prava svojine ili kog drugog stvarnog prava.

\section{b. PRESUMPCIJE}

2. NASLOV DO KOGA POGLED NE DOSEŽE. Iznad člana 9. Nacrta stoji naslov „Pretpostavka imaoca“, a stav 1. tog člana glasi ovako: „(1) Dok se, u skladu sa zakonom ne dokaže suprotno, lice upisano u javnom registru kao imalac stvarnog prava smatra se imaocem tog prava, a držalac, ako zakonom nije drukčije propisano - imaocem prava kome odgovara njegovo postupanje u pogledu stvari, osim prema vlasniku stvari." U pogledu toga Breneselović tvrdi (na str. 187) ovako: „Iz same rečenice ne proističe da li se naznaka 'dok se ne dokaže suprotno’ odnosi samo na slučaj kada je neko kao imalac prava upisan u javni registar, ili se podjednako odnosi i na slučaj kada pretpostavka proističe iz državine."

Doista ne vidim odakle ta dilema kada se reči „dok se ne dokaže suprotno" nalaze na početku odredbe, pa bi ograničavanje njihovog važenja na samo neki deo rečenice moralo jezički biti označeno. Uostalom, ako se samo malo podigne pogled, tek do naslova tog člana, vidi se da on govori o pretpostavki imaoca prava. Naslov člana, zna se, takođe ima normativni značaj jer je deo propisa, tako da se ne sme zanemarivati, pa ni kada se tumači odredba čiji naslov predstavlja. A ne znam kako bi se moglo pomisliti da se naslov, koji je naslov celog člana, odnosi samo na jedan deo člana (samo na onaj koji presumira da je upisani imalac prava ili samo na onaj koji presumira da je držalac imalac prava). 
3. PRAVNO RAZMNOŽAVANJE DEOBOM. Sve bežeći od „dve potpuno zasebne misli i norme" u jednoj istoj rečenici člana 9. stav 1. Nacrta, i sve hoteći da ih razdvoji, razdelio je član u svojoj preformulaciji u dva stava. Drugi njegov stav bi imao glasiti ovako: „(2) Za držaoca se pretpostavlja da [osim državine] ima i [stvarno] pravo radi čijeg vršenja stvar drži, osim ako je zakonom drugačije propisano“" (str. 187).

Jedna je norma u članu 9. stav 1. Nacrta, da se imaocem stvarnog prava smatra onaj ko je kao imalac stvarnog prava upisan u javnom registru, a druga, da se imaocem stvarnog prava smatra onaj držalac koji sa stvari postupa kao imalac stvarnog prava. Breneselovićev drugi stav, za pakost, više nije doneo istu tu drugu misao koja je bila sadržana u članu pre separacije. Nego ju je obogatio. Breneselović bi, naime, da se za držaoca smatra još i da je i - držalac: „za držaoca se pretpostavlja da ima državinu“. Dakle, ne više samo, kako je bilo pre separacije - da je držalac imalac prava, nego uz to još i da je držalac. Kod njega se separacijom dve misli i dve norme, odvajanjem jedne od druge, dobijaju tri misli i tri norme. Neka baš samosvojna pojmovna jurisprudencija. Ali, nije svaka jezička i nomotehnička separacija ujedno i sadržinska melioracija. Nevolja je baš u tome što ta, tako porođena treća misao i treća norma (da je držalac držalac, odnosno da se držalac ima smatrati držaocem) ne postoji uopšte u stvarnom pravu. I što je takvu niko nikada do sada nije hteo, niti bi je iko ikada hteo, a nisu je hteli, niti bi je hteli ni tvorci Nacrta. Ne bi je hteo verovatno ni Breneselović, da je, odnosno kada bi shvatio da je potpuno nefunkcionalna. Sve su pravne norme smislene samo ako se njima išta postiže, jer su sve odreda sredstva za neki cilj. Ovakva norma je sredstvo ni za šta, dakle, nesredstvo, i tako nenorma. Neke druge norme o presumpcijama povezanim sa državinom jesu sredstva, hoću reći, nečem služe: smislena je, recimo, presumpcija savesnosti - to što se za držaoca smatra da je savestan, i presumpcija svojinske državine - što se za držaoca smatra da je svojinski, i presumpcija kontinuirane državine - da je imao neprekinutu državinu. Ali, da se za držaoca smatra da je držalac, taj pravni circulus vitiosus nije drugo do nonsens. - Breneselović, uz to, ne ume kako valja da formuliše ni samu presumpciju da je držalac imalac prava. Pošto kod njega ona glasi: za držaoca se pretpostavlja da ima stvarno pravo radi čijeg vršenja stvar drži (str. 187) - ovo izlazi na to da držalac stvar drži da bi vršio pravo. To je preusko, jer odgovara samo onom držaocu koji ima pravo i koji državinu vrši da bi vršio pravo. Međutim, presumpcija da držalac ima pravo, važi za svakoga ko se ponaša kao imalac prava, bio on to ili ne, imao, dakle, pravo ili ga nemao. I kada nema pravo, ako se ponaša kao da ga ima, makar znao da ga nema, pa prema tome makar i ne vršio državinu da bi vršio pravo (i ne držao stvar da bi vršio pravo), smatraće se da pravo ima, dok se ne dokaže suprotno. A, ni $\mathrm{u}$ jednom takvom slučaju ne može se reći za držaoca da državinu vrši da bi vršio pravo, jer se ne može vršiti nešto što se nema, i što se zna da se nema, i što se može i ne želeti imati. Ne može se reći da neko ko nema pravo da stvar 
drži, stvar drži da bi vršio pravo koje nema. Pravo se može vršiti samo ako se ima, a ono što se nema ne može se ni vršiti. Ili, možda, i ovde to omogućuje neki „suštinski pojam“ (str. 203), koji je ostao skriven tvorcima Nacrta.

Kao poboljšanje reklamira formulaciju: „Imalac stvarnog prava je lice koje je u javnom registru upisano kao njegov imalac, osim ako se ne dokaže suprotno" (str. 187). Na taj je način preformulisao član 9. koji u Nacrtu glasi: „Dok se, u skladu sa zakonom ne dokaže suprotno, lice upisano u javnom registru kao imalac stvarnog prava smatra se imaocem tog prava, ...". Nije ni opazio da je, prigovarajući zbog toga što član „u jednoj rečenici objedinjuje dve potpuno zasebne misli i norme" (str. 186), ovakvom preformulacijom jednog njegovog dela promenio ni manje ni više nego čak smisao odredbe. Umesto jedne od one dve misli i norme, koje su u članu bile sadržane, nemarom je u odredbu uneo treću misao odnosno normu. Posve drugačiju. Koju ni sam ne bi poželeo da je, osim formalnoj strani (formulaciji), posvetio dužnu pažnju i sadržini. Tako preformulisana, ona sada kaže za nekoga ko nema stvarno pravo da ga ima samim tim što je upisan u javnom registru. Gotovo kao da smo u Torrensovom sistemu. Što niko od tvoraca Nacrta nije želeo, a verujem ni bilo ko drugi u Srbiji, pa valjda ni on sam. U svakom slučaju, nepažljiva preformulacija krije razliku od, ni manje ni više, nego jedne cele materijalne pravne koncepcije. Jer, ono jedino što je prihvatljivo, a što je i naša čvrsta tradicija u zakonodavstvu, praksi i teoriji, kako je i formulisano u Nacrtu, jeste to: da se za upisanog smatra da je imalac prava, dok se ne dokaže da nije, a nikako: da upisani jeste imalac prava i kad nije, što bi značilo da prestaje da bude imalac tek ako se i kad se dokaže da nije. A svaka takva - materijalna - greška grdno je teža od jezičkih nepravilnosti, makar ih i bilo u izvornoj formulaciji, a nema ih. Da bi se u praksi izbegla materijalna greška zakona, moralo bi da se ne primeni norma koja sadrži takvu formulaciju. Dakle, moralo bi se odstupiti od zakona, ne poštovati ga. Na kraju bi i zakonodavac naknadno menjao zakon, jer se u pravnoj državi nikome ne mili da postupa contra legem. Nijedna pre/formulacijska nepažnja nije toga vredna. Manje košta biti pažljiv.

4. IZGUBLJENI U DEOBI. Izreka Breneselovićeve osuđujuće presude istom tom članu 9. stav 1. Nacrta sadrži još i ovakav stav: „Na kraju rečenice dodata je naznaka 'osim prema vlasniku stvari', bez da je ona jezički, pa time i misaono, korektno povezana sa ostatkom rečenice: 'držalac se smatra imaocem prava osim prema vlasniku stvari. Štagod da su pisci zakona želeli da kažu, to se tako na srpskom jeziku ne može reći“ (str. 187).

Pri bekstvu od demona (dve misli i dve norme) koje je video u ovoj za njega zlosrećnoj odredbi člana 9. Nacrta, Breneselović je uspeo da izgubi i jedan njen nikako nevažan deo. Deo koji je normativan, a ne ukras ili beznačajni privezak. To što se taj deo nalazi na kraju odredbe, ne znači da je normativni patrljak, iole manje važan od početka ili sredine odredbe. Uprkos 
tome, deo koji u Nacrtu kaže „osim prema vlasniku stvari“, zalud ćemo iskati u Breneselovićevoj preradi člana 9. Sve brinući za dobrobit srpskog jezika na kome se, kako reče, ne može reći tako kako je u Nacrtu rečeno, on je ono što je u Nacrtu ipak rečeno („osim prema vlasniku“), jednostavno posve izbacio iz odredbe. Čime ju je obogaljio. Jezička i nomotehnička separacija kao sadržinska deteriorizacija. - Da se ,jezički, pa time i misaono“ htelo da reči „osim prema vlasniku“ predstavljaju izuzetak i od presumpcije da je registrovano lice vlasnik, a ne samo od presumpcije da je držalac vlasnik, tada te reči ne bi bile napisane na kraju rečenice, i to posle zareza, koji, zna se, označava da se ono što je posle zareza napisano odnosi samo na ono što u odredbi zarezu prethodi (a to je držalac), a ne da se odnosi na celokupan tekst odredbe (uključujući registrovanog). Osim toga, onim čitaocima te odredbe koji su pravnici ne bi smelo biti nepoznato da za javne registre važi načelo pouzdanja u tačnost, zbog koga se smatra da postoji svako registrovano stvarno pravo, a ne samo svojina. Zato nema mesta za dilemu da li reči „osim prema vlasniku" predstavljaju izuzetak i od presumpcije da je registrovano lice vlasnik, ili samo od presumpcije da je držalac vlasnik. Pošto državina (i kada ima nekakav publicitet) nema publicitet ni sličan javnim registrima, ${ }^{4}$ to u pogledu državine važi da u odnosu držaoca sa vlasnikom nije na snazi pretpostavka da na vlasnikovoj stvari držalac ima ograničeno stvarno pravo čijoj sadržini odgovara držaočevo ponašanje, nego se pravo ima dokazati.

\section{c. DRŽAVINA}

5. EH, TE DEFINICIJE. „Ako se u Nacrtu Zakonika državina odredi kao faktička vlast (član 36), a zatim po potrebi pojam državine doradi tako da se u tačno određenim slučajevima uzima da državina postoji i kada nema stvarne vlasti, i obrnuto $u$ tačno određenim slučajevima da ne postoji kada takva vlast postoji, onda to više nije nikakav tipski pojam, već običan enumerativni pojam - pojmovna konstrukcija za koju je čisto označavanja radi upotrebljena reč državina“" (str. 204).

Pre će biti da je Breneselovićev izraz „običan enumerativni pojam“ jedna obična nespretnost (kao da je bilo koji pojam, bio on enumerativan ili kakav već, neobičan pojam ili običan pojam), nego li potcenjivanje enumerativne definicije. Jer, ona to naprosto ne zaslužuje: legitimna je kao što su i druge vrste definicija. - Tvrdeći da u Nacrtu nije posredi „nikakav tipski pojam, već običan enumerativni pojam“, Breneselović brka tipsku definiciju kao vrstu intenzionalne definicije i enumerativnu definiciju kao vrstu ekstenzionalne definicije. Nacrt, međutim, ne sadrži nikakvu enumerativnu definiciju državine.

4 Od novijih analiza nepodesnosti državine da bude sredstvo publiciteta, i o tome da u stvarnom pravu koje se tiče pokretnosti ne važi princip publiciteta, up. Tobias Quantz, Besitz und Publizität im Recht der beweglichen Sachen, Berlin 2005, Jens Thomas Füller, Eigenständiges Sachenrecht?, Tübingen 2006, str. 13. i d., 244. i d. 
Navodi, istina, razne pojavne oblike državine, definisane posredstvom raznih svojstava (fizičku državinu, državinu stanja, državinu u mirovanju, posrednu državinu, državinu nesposobnog za rasuđivanje i dr.). Ali ih ne navodi tako da zatvara njihov broj, tj. ne nabraja sve one pojave koje predstavljaju državinu. Dok enumerativna definicija pojam koji definiše iscrpljuje upravo nabrajanjem njegovih pojavnih oblika, dotle pojavni oblici državine koji su navedeni u Nacrtu ne iscrpljuju pojam državine. Samim tim što Nacrt nije zatvoreno definisao pritežanje (videti član 43. Nacrta), nije zatvoreno definisao ni državinu. - Mada joj Breneselović upravo to poriče, definicija državine kao faktičke vlasti u članu 36. Nacrta jeste definicija državine kao tipa. ${ }^{5}$ A to jeste upravo iz razloga koje navodi Breneselović: „Tipovi su otvoreni pojmovi utoliko što im se ne može unapred iscrpno odrediti sadržaj, utoliko što je nemoguće unapred reći šta je sve držanje odnosno stvarna vlast, a šta ne“ (str. 204). Baš tako. Iako, dakle, zna šta je tipski (otvoreni) pojam, ne prepoznaje u članu 36. Nacrta upravo takav, tipski (otvoreni) pojam državine.

6. DRŽAVINA KAO TIP ILI KAO SVAŠTARA. „No, iako je pojam državine otvoren pojam odnosno tip, to ne znači da se u njega po nekoj spoljnoj potrebi, recimo da bi se objedinila (pre)dispozicija jedne pravne posledice, može staviti bilo šta“" (str. 204).

Posredi je doista veliki nesporazum između Breneselovića i bilo kojeg zakonodavca (a ne samo autora Nacrta) koji u normi mora da se služi izrazom kakav je državina, a čije značenje ne može da odredi na način klasične definicije (genus + differentia specifica) zato što ne postoji specifično svojstvo državine koje bi, da ga ima, omogućilo da se norma o državini primeni uvek onda i samo onda kada postoji to svojstvo. Ako neće da upotrebi samo izraz državina, a da ga baš nikako ne definiše, pa odredi državinu bar posredstvom njenog tipskog obeležja (faktičke vlasti), tada će norma o državini važiti kako onda kada je ta tipska osobina u punom obimu, tako i onda kada je ima tek u nekom stepenu, ali i onda kada je nikako nema. Breneselović kaže da „sadržaj“ tipskog (otvorenog) pojma „ne proističe iz konstruktorskog talenta pisaca zakona ili nekog drugog lica koje se pojmom koristi, već vodećeg sadržaja pojma, što je u slučaju državine držanje (stvarna vlast)“ (str. 204). Ostavimo na stranu pitanje: „Vodeći“ sadržaj pojma - šta je to (i kakav je ostali sadržaj pojma). Sadržaj državine, dakle, proističe iz vodećeg sadržaja državine, precizno: iz stvarne vlasti. Da je to doista samo proisticanje, ne bi ni bilo problema sa državinom i primenom normi o državini. Upravo ih i ima zato što nije

5 Upućivanja na inostranu pravnu književnost o tipu, kod V. V. Vodinelić, Javno i privatno pravo, Beograd 1986, str. 810. i d., 849. i d., 852. i d., isti, Takozvana zloupotreba prava, Beograd 1997, str. 217. i d., isti, Stvarna prava u medunarodnom privatnom pravu (Koliziono ra/stezanje supstancijalnog pojma i kruga stvarnih prava), u: Liber amicorum Dobrosav Mitrović, Beograd 2007, str. 27. i d. O definiciji državine (i pritežanja) kao tipa, v. kod V. V. Vodinelić, Državina i pritežanje, u: isti i dr., Promene stvarnog prava u Srbiji, Beograd 2004, str. 55. i d. 
tako. Pošto je faktička (stvarna) vlast svojstvo zajedničko kako raznim pojavnim oblicima državine, tako i raznim pojavnim oblicima pritežanja, ona ne predstavlja definitorno svojstvo koje bi bilo dovoljno i da se bez ostatka definiše pojam državine, i da se tako odredi pojam pritežanja, a i da se oni međusobno razgraniče. Opet, to što faktička vlast samo tipski određuje državinu ne znači da se u pojam državine „može staviti bilo šta“, niti da se stavlja „bilo šta“, niti da je Nacrt stavio „bilo šta“. Nego, kada se pita da li neka pojava predstavlja državinu, uzima se u obzir da li je za tu pojavu primeren pravni režim predviđen za državinu. Ako jeste primeren, tada osobine svake takve pojave (fizičke državine, državine stanja, državine u mirovanju, posredne državinu, državine nesposobnog za rasuđivanje i dr.) ulaze u sadržinu pojma državine. I to opet kao tipske osobine, jer i kada nije data neka od tih osobina, državina je posredi ako postoji koja druga takođe tipska osobina državine.

7. S TRIKOM ILI BEZ NJEGA, PITANJE JE SAD? Breneselović tvrdi da se u članu 39. stav 2. Nacrta „državina arbitrerno zagovara kod lica nesposobnih za rasuđivanje i kada nemaju stvarnu vlast" (str. 203). To tvrdi zato što je stvarna vlast, i samo ona, za njega državina. Državina je svaka stvarna vlast i samo je stvarna vlast državina.

Međutim, stvarna (faktička) vlast nije dovoljno obeležje da bi neko bio držalac, tj. podvrgnut državinskom pravnom režimu. Dobri razlozi, a ne arbitrernost, leže u osnovi toga zašto pravno postoje i državine bez faktičke vlasti, kao i faktičke vlasti koje nisu državina. ${ }^{6}$ „Nomotehnički trik“ (str. 196) koji on zagovara: da se samo faktička vlast smatra državinom, a da se ostalo (kada nema državine) izjednačava sa državinom („shodno važenje“, str. 196), u pravu nam je potreban, jednako kao i, na primer, fikcija, samo onda kada nešto u pravu ne možemo bez toga da postignemo. U slučaju državine možemo da primenimo željeni (državinski) pravni režim i bez tog „trika“. „Trikom“, uostalom, ovde ne postižemo ništa: podjednako kao i bez „trika“, neotklonjiva ostaje otvorenost državine kao tipa. ${ }^{7}$ To jest, ostaje neizbežno da se tek stvaranjem tipičnih grupa životnih slučajeva (vrsta državine) reši pitanje primerenosti primene ili neprimene državinskog režima na razne slučajeve kako postojanja tako i nepostojanja faktičke vlasti. „Trik“ koji on zagovara vodio bi samo tome da u tom nastojanju moramo da operišemo sa tri pojave: državina - (neimenovana) pojava koja nije državina ali za koju važi što i za državinu, i - pritežanje. Pojava kojoj on ne daje nikakvo ime a za koju bi, iako nije državina, trebalo da važi što i za državinu, i sama bi kad-tad takođe bila nazvana državinom. Kako zbog istovetnosti pravnog režima koji za nju važi, tako i zbog težnje ekonomiji u izražavanju. Budući da se svuda državinom nazivaju razne situacije bez faktičke vlasti (setimo se, na primer, samo posredne državine i državine naslednika), to bismo i mi samo tranziciono operisali sa

6 Iscrpnije o tome V. V. Vodinelić, Državina i pritežanje, u: op. cit. (u prim. 5), str. 55. i d.

7 I o tome V. V. Vodinelić, Državina i pritežanje, u: op. cit. (u prim. 5), str. 63. i d. 
tri pojave, koje bi opet ubrzo završile kao dve. Umesto što to isto (i odmah) ovako možemo da ostvarimo i samo sa dve kategorije: državina (bila ona sa ili bez faktičke vlasti) i pritežanje. Još uvek nije zastarela Occamova poruka: ne umnožavajmo nepotrebno entitete (Nunquam ponenda est pluralitas sine necessitate). Njeno važenje ne prestaje ni pred vratima prava. - Tipične grupe životnih slučajeva koje zovemo državina bez faktičke vlasti, nadmašuju po broju slučajeve državine sa faktičkom vlašću. Zato bi rezultat primene državinskog režima na nedržavine (dakle, rezultat zagovaranog „trika“) bio taj da bi bilo više onih slučajeva kada se državinski režim primenjuje na situacije u kojima ne postoji ono što Breneselović smatra suštinskim za pojam državine, a to je faktička vlast, nego situacija u kojima ima faktičke vlasti. Ukratko, državinski režim bi se odnosio više na nedržavine nego na državine. Preporučujući sa „trikom“ implicite i takvu njegovu posledicu, ne reče samo, koje je to nomotehničko pravilo da se pravni režim koji se zove po određenom pojmu dominanto primenjuje na situacije kojima taj pojam ne odgovara. Po kom se to nomotehničkom pravilu pravni institut (državine) gradi tako da se primenjuje na situacije koje se ne mogu zvati njegovim imenom.

8. TOBOŽNJOST STVARNOG I ZBILJNOST TOBOŽNJEG. Razmatranja (na str. 203) povodom državine Breneselović započinje dvema dezinformacijama. Jedna zbunjuje jer glasi: „Zakonopisci ... državinu nisu odredili kao stvarnu vlast“. Zbunjuje pošto Nacrt već u prvoj odredbi Dela II, posvećenog državini i pritežanju, državinu određuje kao stvarnu („faktičku“) vlast (član 36). Sledeća je prećutkivanje delova iz državinske stvarnosti koji mu nisu po volji: „Sopstvena (vlasnička) državina i korisnička državina u stvarnosti nisu podvrste državine, kako bi iz stilizacije čl. 36 Nacrta Zakonika i njegovih drugih odredbi proizilazilo, već pomoćne konstrukcije pri formulisanju činjeničnog skupa održaja i nekih drugih pravnih instituta kod kojih su kao tobožnja vrsta državine u stvarnosti označena dva nezavisna uslova: (1) državina kao stvarna vlast i (2) shvatanje stvari kao svoje ili tuđe (na nemačkom: Willensrichtung)“. ... U predloženoj regulaciji zakonopisci ... su i prevideli provizoran domašaj naučne konstrukcije sopstvene (vlasničke) i korisničke državine i fiksirali ih kao ontološke podvrste državine“ (str. 203). Šta god Breneselović tvrdio, u toj stvarnosti čiji bi hteo da bude glasnogovornik, a ne u teoriji odvojenoj od života, svaka faktička vlast koja je državina pojavljuje se ili kao vlasnička, ili kao korisnička, ili kao dužnička, koju Breneselović prećutkuje. Nema državine (faktičke vlasti) koja bi odgovarala nečem četvrtom, a ove tri vrste ne samo da približavaju (konkretizuju) apstrakciju „stvarna (faktička) vlast", nego su i pravno važne za primenu raznih pravnih instituta (održaja i dr., što ne spori ni Breneselović, str. 203). Neka onda sam čitalac pronikne u pravac i smisao Breneselovićevog neslaganja sa svime time kada se poziva na „suštinske pojmove“ („nerazlikovanje didaktičnih i pomoćnih naučnih konstrukcija od suštinskih pojmova“, str. 203). - Iako sam sudelovao u formuli- 
sanju odredaba Nacrta, nije mi znano koji bi to bili udžbenici čije su „šeme“ navodno kod državine „preslikane“ „u zakon“, kako tvrdi Breneselović, i to „pogubno“ (str. 203). Ali znam: da nije prećutao baš tu, treću vrstu državine dužničku, ne bi ni mogao tvorcima Nacrta pripisati da su preslikavali udžbeničke šeme, pošto, po mom najboljem znanju, upravo te, treće vrste državine nema nigde u udžbenicima. Pravniku je, inače, valjda znano da svojinska i korisnička državina nisu tek „udžbeničke šeme“, nego su kod kuće u raznim propisima.

9. ZBILJNOST TOBOŽNJEG I TOBOŽNJOST STVARNOG. U pogledu definicija nekih vrsta državine tvrdi (na str. 206) da one, „uz sve bogatstvo upotrebljenih izraza i podela, suštinski ne definišu pojam i žive nadalje kao zasebna zakonodavčeva stvarnost naspram života“.

Učenje o definicijama poznaje razne vrste definicija. Ni to učenje mi ne pomaže da razumem suštinu ove primedbe. Samo slutim, dakle, možda i pogrešno, da Breneseloviću nije poznata raznovrsnost upravo životnih situacija u pogledu kojih je potrebno da pravnik učini osnovni izbor: hoće li na njih primenjivati državinski pravni režim ili ne, a što podrazumeva da te situacije kvalifikuje ili ne kvalifikuje kao državine. A pošto o istoj situaciji razni pravnici mogu imati razna mišljenja (o čemu svedoči uporedno pravo), onda je dobro da zakonodavac, ako već ima o tome stav, u propisu iskaže svoje opredeljenje o vrstama državine - koje će tada biti obavezujuće.

\section{d. SVOJINA}

10. KUM NIJE DUGME. Prvo će reći: „Kod nas je može se reći i uobičajno da se poseban izraz koji stoji za neki pojam naznačava u zagradi nakon definicije pojma ili neke druge sekvence teksta koja je sa takvim posebnim izrazom na neki način logički povezana. Takva veza se u Nacrtu na više mesta ne vidi ili je jezički isiljeno uspostavljena." Kao ilustraciju navodi i to što je u odredbi o svojini (član 79) posle reči „Pravo svojine je najšire pravo lica“ u zagradi navedeno: „vlasnik“ (str. 197-198). Potom je ipak spoznao, doduše samo do stepena verovatnoće, da ,je naizgled bez razloga naglašeno da je to najsveobuhvatnije pravo lica (koga inače?), verovatno da bi se stvorio prostor da se u zagradi naznači da je zakonski naziv za titulara prava 'svojine' vlasnik“ (str. 198).

Nekako mi ne deluje iskreno da nije shvatio da „vlasnik“ nije jedini mogući naziv za imaoca prava svojine. Kao ni da mu je promaklo da navođenje reči vlasnik nije ovde ništa manje važno od bilo kakve druge nominacije kojom se čini izbor između dva ili više imena koja dolaze u obzir. Zato je jalovo i njegovo naizgled nadmoćno iščuđavanje - „pravo lica (koga inače?)“. Svakako da je pravo lica posredi (osim kada je svojina bezsubjektna), ali je na zakonodavcu i posao da bude kum tom bezličnom licu. Pošto u srpskom jeziku nema doslednosti hrvatske terminologije (vlasništvo - vlasnik), bar još 
„sopstvenik“ pretenduje na to da se njegovo ime uzme u obzir pri imenovanju titulara svojine. Baš to je bio izbor Predosnove za Nacrt Zakona o pravima na stvari od 1964, član 14, passim, Civilnog kodeksa od 1966, član 150, passim, Nacrta zakona o pravu svojine i drugim stvarnim pravima na nepokretnostima od 1978, član 10, passim, Nacrta Zakona o pravu svojine i drugim stvarnim pravima od 1980, član 5, passim, Nacrta Zakona o pravu svojine i drugim stvarnim pravima od 1989, član 32, passim. Malo li je. A ni Breneseloviću nije mrsko da kaže za stvar da je „sopstvena“ (str. 199-200), a ne „vlastita“ ni „svoja“, i da je državina „sopstvena“ (str. 203) a ne „vlasnička“. Doista, koliko je, dakle, nužnosti u tome da kada je pravo - „svojina“, a stvar - „sopstvena“, imalac svojine na sopstvenoj stvari bude - „vlasnik“? Prema tome, kum u ovom slučaju nije baš takvo dugme.

11. VLASNIK NEMA PRAVO SVOJINE. „Titular službenosti ima pravo služenja, pravo da se, recimo, određenim zemljištem posluži, on ima i službenost na poslužnom dobru, ali jezički nema pravo službenosti (v. čl. 298 i sl.)“, tvrd je u tome Breneselović (str. 196). Tako tvrdi i za druga prava: titular ima svojinu na stvari, ali nema pravo svojine na stvari itd. To bi značilo da biti „titular“ (biti vlasnik, plodouživalac, zakupac itd.) znači da taj ima pravni institut na stvari, pošto je svojina (službenost, zakup itd.) ime za pravni institut, a da nema pravo svojine na stvari. Stvar je, dakle, objekt pravnog instituta, a nije objekt prava svojine!? Ako se htelo reći da je svojina naziv za pravo koje se ima na stvari, ali da to pravo ne sme da se zove pravo svojine nego samo svojina, ne verujem da će napraviti karijeru takva distinkcija i terminologija, a ni njen pronalazač s njom.

12. NAHOĐENJE PO SVOJOJ SLOBODNOJ VOLJI. „Koje je uže pravo od prava svojine koje neko lice može imati da po svom nahođenju postupa sa svojom stvari?", da bi to trebalo napisati u odredbi o svojini - pita se Breneselović, kudeći što je sve to uopšte napisano u odredbi o svojini (na str. 198). Odgovor: Nijedno drugo, zato to i nije napisano ni kod kog drugog stvarnog prava. I zato je to napisano samo kod svojine. Uz to, pravo svojine nije jedino pravo koje se ima na svojoj stvari. Svojinska ograničena stvarna prava (uređena i u Nacrtu, čl. 86, 93, 298, 331, 337, 349, 394, 440, 585) takođe su prava vlasnika - prava na svojoj stvari. Ali vlasnik, iako je njihov imalac, i iako je stvar na kojoj ih ima njegova, ne može da ih na toj, svojoj stvari vrši po svom nahođenju. Ne može na osnovu njih da sa svojom stvari, iako je njegova, postupa po svom nahođenju. A na osnovu svojine, može.

Nalazi da bi, umesto „po svome nahođenju“, bilo „izvrsno“ reći da vlasnik „slobodno i po svojoj volji ...." (str. 200). Mada je na drugim mestima protiv gomilanja reči i protiv udvajanja (čak i kada se radi o tome da je širim izrazom obuhvaćeno i ono što označava uži izraz, a što iz određenog razloga uprkos obuhvaćenosti širim izrazom valja posebno naglasiti još i užim izrazom, vidi. III.e.26. i III.g.29), ovde mu ne smeta što ako je „slobodno“ ne može ni biti po 
tuđoj volji, niti ako je po svojoj volji, ne može biti nego slobodno. Mada mu drugde smeta i delomično podudaranje, ovde mu ni potpuno ne bode oči.

Smeta mu izraz „po svome nahođenju“, jer smatra da „po svome nahođenju“ znači manje nego „po svojoj volji“, kao primerenom izrazu. „Dati nekome da nešto čini prema svom nahođenju (viđenju, shvatanju) znači dati nekome za pravo da sam utvrđuje (prosuđuje, nalazi) šta valja činiti uz nerazdvojivu konotaciju da ispravno ili barem uputno činjenje objektivno kao preddato postoji i da je pojedincu samo prepušteno da izradi nalaz te objektivne osnove" (str. 199). Ali, ma kako se trudio da svojinu pokaže kao pravo čiji se titular ne susreće u društvu i pravnom poretku ni sa čime kao „preddatim“ i ni sa kakvom „objektivnom osnovom“, on već u sledećoj rečenici kapitulira kontradikcijom da je suština svojine u „potpunoj slobodi u širokim zakonskim okvirima" (str. 199). U vlasnikovom (i Breneselovićevom) pravnom okruženju taj okvir (ta „preddatost“, i ta „objektivna osnova“) itekako postoji u vidu ograničenja svojine, što postavljenih međunarodnim ratifikovanim aktima, što Ustavom ili zakonom, što opštim ograničenjima, važećim za svaku svojinu, što specijalnim. Ni Breneselović nije još pre, uoči ovog mesta mogao a da ne konstatuje kako su vlasnikova ovlašćenja „nekada toliko sužena da se dozvoljene radnje, odnosno ovlašćenja vlasnika na prste mogu pobrojati“ (str. 199). Kako neko reče, ni najlepša devojka ne može da dâ više nego što ima. Kod svakog prava, ne samo kod svojine, isto je: u njegovim okvirima titular je potpuno slobodan. Samo je pitanje, koji su mu okviri.

13. PRIPADANJE - ÜBER ALLES. „Pravo svojine se ili može odrediti kao najšire pravo da se postupa sa stvari ili pak kao pravo da se po sopstvenom nahođenju postupa sa stvari, ali je besmisleno reći da je to najšire pravo da se po sopstvenom nahođenju postupa sa stvari“. „... svojinska ovlašćenja“ su „i po prirodi stvari i po Nacrtu Zakonika, samo posledica toga što je neka stvar moja“. „... suština svojine nije u ovlašćenjima, već u imanju nečega kao svog iz čega proističu razna pojedinačna prava (ovlašćenja), nekada toliko mnogostruka da sudbina stvari samo od volje njenog vlasnika zavisi (šolja za kafu), a nekada toliko sužena da se dozvoljene radnje, odnosno ovlašćenja vlasnika na prste mogu pobrojati (zemljište uz morsku obalu)“ (str. 198. i d.).

Svojina je najšire pravo po broju ovlašćenja, po sadržini ovlašćenja, i po načinu vršenja ovlašćenja. Da nije „besmislica“ da je svojina najšire pravo na stvari, pokazuje i to što, kako god pravnom normom vlasnikova ovlašćenja bila proređena u pogledu broja, osiromašena u pogledu sadržine, a sputana u pogledu načina vršenja, ni tada nema nikog drugog ko bi mogao više od vlasnika. Svojina je najšire pravo, u trostrukom pogledu: zato što jedina predstavlja skup najvećeg broja ovlašćenja povodom stvari, većeg od bilo kog drugog prava; zato što jedina predstavlja skup ovlašćenja najvećih po sadržini, većih od istoimenih ovlašćenja iz sastava drugih prava; zato što jedina ovlašćuje titularu da ovlašćenja vrši ili ne vrši na način koji sam odabere (po svom 
nahođenju), dok ostali moraju obzirno, kao dobri domaćini. Najveći skup ovlašćenja = najveći broj ovlašćenja povodom stvari. Skup najvećih ovlašćenja = najvećih po sadržini i po načinu vršenja. Najkraće: najveći skup najvećih ovlašćenja. Među tim ovlašćenjima proprietas - ovlašćenje pripadanja stvari vlasniku, samo je jedno od ovlašćenja, a ne izvor ostalih ovlašćenja. Sva vlasnikova ovlašćenja, naravno, proističu iz pravne norme o svojini, a ne jedna iz drugih, a ni ostala iz ovlašćenja pripadanja stvari vlasniku. Imaocima ograničenih stvarnih prava stvar ne pripada, pa iako nemaju ovlašćenje pripadanja stvari, i oni u pogledu stvari imaju neka ovlašćenja koja ima vlasnik. Druga vlasnikova ovlašćenja ne stoje sa pripadanjem stvari u odnosu jednostrane određenosti. Nego su u odnosu koordinacije: nijedno od njih nije određeno drugim, nego tek zajedno čine svojinu. Iskreno, nisam u stanju da spoznam šta je to što je toliko nepojamno u rečenici da je svojina najšire pravo da se po svome nahođenju postupa sa stvari, da zaslužuje etiketu „besmisleno“.

14. SVOJINA, TA NEPREVRELA. Smetaju mu, kako se izrazio kulinarskom terminologijom, „neprevreli“ stavovi u Nacrtu (str. 203), a sam zagovara neprevrele stavove umesto prevrelih. Tako, samo zato što mu smeta, minorizuje kao „tobožnjeg pravnog klasika“ (str. 198) stav da je pravo svojine najšire pravo na stvari. I to čini uprkos svoj dominantnosti tog stava i u vremenu i u prostoru, uprkos, dakle, svoj njegovoj prevrelosti. Takođe je, mada je i on i te kako prevreo, pojam „pravo svojine“ za njega samo „pseudopojam 'prava svojine““ (str. 199). Prevrelost tog prava nije ga sprečila da kaže da „Ne postoji nekakvo subjektovo 'pravo svojine' kao upotrebljivi pravni pojam" (str. 199). Ni druga, ne manje prevrela prava - pravo službenosti, pravo zaloge, takođe nisu prava. Ne zaostaje u neprevrelosti ni ovaj Breneselovićev stav: „Ne stiču ljudi nikakvo pravo svojine (čl. 87 Nacrta), već same stvari“ (str. 199). Uprkos svoj njihovoj neprevrelosti, nijedan od tih usamljeničkih radikalnih negatorskih stavova ne sprečava ga da ih želi u propisu.

15. SVOJINA TROJERUČICA. Bilo bi neinformativno reći u Nacrtu samo to da je svojina pravo po svome nahođenju postupati sa stvari. Redovno se u pravnim izvorima poimence navode i neka ovlašćenja. Breneselović takođe misli da je dobro da se navedu. Njemu se dopada da to budu ova ovlašćenja: držati, koristiti i raspolagati (str. 200, 201). Ne reče samo, zašto baš ona, i zašto samo ona? Na osnovu čega su izdvojena od ostalih i privilegovana? Kao da su jedina, ili kao da se sva druga (upotreba, menjanje namene stvari, isključivanje trećih, zahtevanje predaje od neovlašćenog da je drži, potpuna neaktivnost $\mathrm{u}$ pogledu stvari) mogu svesti na njih, a ne mogu. Tako onda ispade da je proizvoljno što negoduje (na str. 201) zbog toga što su u Nacrtu navedena i neka druga. Bogišiću je u stanju da oprosti opširniji opis svojine, pošto je on OIZ pisao „za zemlju bez moderne pravne kulture i bez pravnika“. Čitaocu retorički prepušta da sam presudi nije li „u savremenim prilikama“ „bolje i lepše" da se ostane pri trijadi iz Zakona o osnovama svojinsko-pravnih odno- 
sa - držanje, korišćenje, raspolaganje. O lepoti ne bih, ali bolje nije, jer nam nije dovoljna Svojina-Trojeručica nego je potrebna Svojina po liku boginje Durge, sa svim njenim rukama. Izgleda da je brzo zaboravio da je pomenuti zakon, takođe u našim „savremenim prilikama“ (str. 201), obezvređivao svojinu, u prilikama koje takođe nisu bile „bez pravnika“ (str. 201), niti bez „ustavno-zakonske veze“ između „opšte slobode postupanja i slobode postupanja sa sopstvenom stvari“ (str. 200), i koje su podosta trajale. Baš radi učvršćivanja „moderne pravne kulture“ (str. 201) umesan je makar simbolički diskontinuitet sa takvim, takođe savremenim prilikama, u kojima je takođe bilo pravnika, i u kojima je jednako tako postojala ista „ustavno-zakonska veza“ između opšte slobode postupanja i slobode postupanja sa sopstvenom stvari, pa to ništa nije pomoglo afirmaciji svojine. To što Breneselović ne uviđa, uvideli su neki koji poseduju širi pogled na prava tranzicijskih zemalja. Ulrich Drobnig i Christa Jessel-Holst, koji su se bavili pitanjem obima uređenja svojine u Nacrtu, kažu ovako: „... danas je potreban poseban napor za povratak opšteprihvaćenim kategorijama stvarnog prava, pre svega stvarnopravnoj centralnoj instituciji svojine. Pored toga je još jedan stvarnopravni kompleks od naročitog značaja za opšti privredni razvoj zemalja naslednica bivše Jugoslavije - pravo stvarnog obezbeđenja kredita. Obe ove centralne pravne institucije sa pravom su najscrpnije uređene u Nacrtu“. ${ }^{8}$ Konstatuju da je svojina regulisana sa oko dvesta članova, dakle „vrlo iscrpno“, i da bi „Ipak ... moglo biti potrebno da se u pojedinačnim slučajevima proveri ${ }^{“ 9}$ „da li regulisanje sveukupno treba da bude tako opširno i detaljno kao u ovom Nacrtu“. ${ }^{10}$ Konkretno govoreći o definiciji svojine, istakli su da su „ovlašćenja vlasnika ... opisana vrlo iscrpno i sveobuhvatno - uključujući i negativno pravo, da ne vrši ovlašćenja koja mu pripadaju“. ${ }^{11}$ Ali opravdanost takvog opisa nisu osporili.

16. MANJAK VIŠKA. Breneselović se zabrinuto pita „kakva je ... korist“ da se u ,jednu sluholomnu odredbu“ člana 87. stavi da se pravo svojine može steći kako od vlasnika, tako i od nevlasnika, ovlašćenog da u svoje ime njime raspolaže (str. 204).

Pustimo druge da na to odgovore: korist je od toga ta što se sticanje od neovlašćenog ne svodi na sticanje od nevlasnika (a non domino), nego se odnosi i na sticanje od vlasnika ( $a$ domino), neovlašćenog, međutim, da raspolaže sa stvari. ${ }^{12}$ Ali, uostalom, neobično je što se takvim tricama i kučinama,

8 Ulrih Drobnig - Krista Jesel-Holst, Nacrt srpskog Zakonika o svojini i drugim stvarnim pravima (iz 2006), u: Ka novom stvarnom pravu Srbije, Beograd 2007, str. 155.

9 Str. 155.

10 Str. 154.

11 Str. 155.

12 O tome da mogućnost da se savesno stiče od svakog neovlašćenog, kako od nevlasnika tako i od vlasnika neovlašćenog da otuđi stvar, predstavlja rešenje koje je „u skladu sa jednom modernom privredom“, v. Ulrih Drobnig - Krista Jesel-Holst, op. cit. (u prim. 8), str. 156. 
kakva su pitanja sticanja prava svojine, uopšte bavi neko ko tvrdi da sticanje prava svojine i ne postoji: „Ne stiču ljudi nikakvo pravo svojine (čl. 87 Nacrta), već same stvari“ (str. 199). Ovo je radikalnije čak i od onog laičkog poistovećivanja objekta prava svojine sa samim pravom svojine, kada laik misli, na primer, da je automobil njegova svojina, pa misli da je kupovinom stekao sam automobil, a ne pravo svojine automobila. Ostaje enigma, kako bi se reklo za one koji postaju titulari prava službenosti, zaloge, zakupa i drugih prava - šta li oni stiču, da li opet samu stvar ili ni nju.

17. ODRON U PREĐAŠNJE STANJE. Odron, tj. odvojeni komad zemlje, kamenje i rastinje koje je dospelo na susednu nepokretnost (kako Nacrt definiše odron u članu 138), nije moguće vratiti u pređašnje stanje, tvrdi Breneselović (na str. 191). Nego da je u pređašnje stanje moguće vratiti „samo ono što je oštećeno - stenu, odnosno zemljište, a ne popadalo kamenje, jer ono do odrona, kao ni odron u smislu zakona, nije ni postojalo“.

Doista, ništa od popadalog nije postojalo kao popadalo pre nego što je popadalo. Ali ni vraćanje popadalog u pređašnje stanje ne znači vraćanje popadalog u stanje nepopadalosti. Pređašnje stanje ovde označava mesto (zemljište) gde su se odvojeni komad zemlje, kamenje i rastinje nalazili pre nego što su se našli na susednom zemljištu. I gde bi se nalazili da nisu popadali. Tamo se i vraćaju. To je jasno iz same odredbe koja kaže da vlasnik „zemljišta“ koje se odronilo usled dejstva više sile može o svom trošku vratiti odronjeni deo tla i rastinje (odron) koje se na njemu nalazilo u vreme odronjavanja. Nije moguće, doduše, da se tamo vrate jezičkim analizama, kako god ih Breneselović sproveo. Ali neka pita vlasnike zemljišta da li bi oni imali, poput njega, teškoće da razumeju šta su im po Nacrtu prava, i kako bi i gde vratili odronjeno. - Na istom mestu kritikuje i to što se odron ne definiše onako kako se definiše u drugim propisima. Zašto ne kritikuje svaki propis koji drugačije od građanskopravnog definiše značenje istih reči kojima se služi? A, kasnije (III.g.27) ćemo još i o tome da je taj prigovor promašen čim se ne zaboravi kako stvari stoje s domenom primene nekog propisa.

18. RADNJA, TA PRAVNO NASUŠNA. „Izražavanje ... treba da bude ... po meri misli koje se žele izraziti. ... u Nacrtu ima i članova u kojima stoji previše reči: nije li bolje zahtevati stvar, nego zahtevati predaju stvari, kako stoji u čl. 184 I Nacrta; nije li bolje obustaviti uznemiravanje, nego prestati sa radnjom uznemiravanja, kako stoji u čl. 195? Zar se ne može prosto govoriti o brisanju prava iz javnog registra, umesto o izvršenju upisa brisanja u javni registar, kako stoji u čl. 12 II Nacrta?"“ (str. 186).

Prihvatam, naravno, opšte stilsko pravilo na koje se Breneselović uvodno pozvao. Ali, ne i Breneselovićevu konkretnu kazuistiku povodom tog pravila. Odgovori na njegova konkretna pitanja su zato: ne, nije bolje; ne, ne može se prosto govoriti ... Jeste naš jezik glagolski, kao i nemački, a ne imenički, kao, recimo, engleski. Od toga ispravno polazi Breneselović, na str. 183. i na- 
stavlja: „Jedno od naših najpoznatijih stilskih pravila je da se u prilikama u kojima se nešto može naizgled podjednako izraziti i glagolom i imeničkom ili pridevskom konstrukcijom, prednost da prostoj konstrukciji sa glagolom“. „U našem jeziku sve što se može izraziti glagolom, treba i izraziti glagolom, jer će tako sagovornik (čitalac, slušalac) mnogo lakše razumeti rečenicu." Mnogo je svedoka da je baš to nejednom rečeno tokom izrade Nacrta, pri formulisanju članova. Išlo se i korak dalje od Breneselovića, naglašavajući da, iako su oba jezika glagolska, nešto ne može da prođe u Nacrtu iako bi dobro prošlo kod Nemaca, pošto oni u većoj meri od nas misle u imenicama. Samo, sve ima svoje granice, pa i upotreba glagola umesto imenica. Zarad ljubavi za izražavanje glagolima ne smeju biti zanemarene one imenice koje predstavljaju učvršćene nazive pravnih instituta, a koje stoje za tačno određenu pravnu sadržinu, jer bi se tako izgubili obrisi onoga što one označavaju. Kada bi se usvojili Breneselovićevi predlozi, to ne bi bilo mnogo drugačije nego, recimo, kad bi se umesto svojine htelo svojiniti, umesto vršenja prava svojine, htelo svojiniti. Naprosto, „brisanje prava iz javnog registra" vrši se upisom, i to upisom brisanja prava, kako se zove ta pravna institucija. Kao što se neki drugi upis zove upis sticanja prava, dok sticanje prava iz javnog registra ne bi bilo to isto. Opet, negatorni zahtev služi postizanju zaštite od uznemiravanja, koje je dvojako: ili se sastoji u stanju koje smeta vlasniku a stvoreno je ranije izvršenom radnjom, ili u ponavljanju radnje koja mu smeta. Kada se sastoji u ponavljanju radnje, zahteva se prestanak radnje koja se ponavlja. I to je to. A, i „obustaviti uznemiravanje“ opet bi se izrazilo kao obustavljanje radnje uznemiravanja, jer se stanje uznemiravanja, kao ni bilo koje drugo stanje, ne može obustaviti, već samo ukloniti, i to opet radnjom, ali radnjom uklanjanja stanja, a ne radnjom obustavljanja stanja. Ni kada Breneselović traži da se „zahtevati predaju stvari“ zameni „Zahtevanjem stvari“, nema na umu da Nacrt uređuje jedan stvarnopravni zahtev, odnosno tužbu, i njihovu sadržinu. A, bitni deo tužbe je tužbeni zahtev. Međutim, „zahtevati stvar“ - to niti odgovara onome šta se u stvarnosti zahteva reivindikacijom, niti se ta formulacija dâ pretočiti u tužbeni zahtev. Laik može da govori o zahtevanju stvari. Pravnik zna da se ne zahteva stvar, nego se zahteva određena radnja (ponašanje) tuženog u pogledu stvari. Ta radnja je predaja stvari: da tuženi preda stvar tužiocu. To se nikako ne uspeva iskazati samim izrazom zahtevanje stvari, nego tek zahtevanjem predaje stvari. Kako bi, uostalom, taj „zahtev stvari“ glasio? „Dužan je tuženi da ... šta!?... stvar tužiocu, u roku od 15 dana, i pod pretnjom prinudnog izvršenja“. Ukratko, stvar se ne može zahtevati a da to ne bude zahtevanje predaje stvari. Važno je da se u propisu baš navede da se zahteva predaja stvari još i zato što izraz „zahtevati“ stvar može da ima i jedno uže, a neodgovarajuće značenje. Ako se ne kaže izričito da se zahteva „predaja“ stvari, „zahtevati“ stvar i ne mora da znači isto što i zahtevati predaju stvari. Zahtevanje stvari, ako stoji samo, podesno je da se tumači šire ili uže. Dovoljno je neprecizno da se u primeni može suziti, recimo, na zahtevanja „vraćanja“ („povraćaja“) stvari. Jer je i zahtevanje povraćaja stvari takođe zahtevanje stvari. Baš tako je urađeno u članu 37. st. 1. i 
2. Zakona o osnovama svojinskopravnih odnosa ${ }^{13}$ (ZOSPO). Pošto zahtevati "povraćaj“ stvari podrazumeva slučaj da je tužilac stvar već imao kod sebe, u tom suženju zahtevanja stvari na povraćaj stvari reivindikacija je dostupna samo onom vlasniku kod koga je stvar prethodno već bila. Što je loše, jer bez zaštite ostaju svi oni vlasnici koji nikada nisu ni postali držaoci stvari, kod kojih stvar nikada prethodno nije bila. Reivindikacija, međutim, ne služi samo vlasnicima kod kojih je stvar prethodno bila, nego svakom vlasniku i to protiv svakoga ko nema ovlašćenja da stvar kod njega bude. Nezavisno od toga da li je ona prethodno bila kod vlasnika ili ne. Ko to razume, razumeće i zašto je zahtevanje predaje stvari bolje od zahtevanja stvari. Ako se ne kaže u Nacrtu da se zahteva "predaja“ stvari, reminiscencija na terminologiju ZOSPO-a, a to znači na propis koji je već više od tri decenije u primeni, i koji su „milioni“ morali da čitaju, mogla bi da produži život uskoshvaćenoj reivindikaciji. Samo je izraz zahtevati "predaju“" stvari u stanju da obuhvati i traženja koja se ne svode na zahtevanje vraćanja stvari. Ko sve to zna, neće se založiti kao Breneselović. Radi se, prema tome, o mnogo ozbiljnijoj stvari od toga da li će se upotrebiti tri reči umesto dve (na šta se svodi Breneselovićev prigovor o višku reči). Potrebna su znanja o nečemu što se ne svodi na pitanje broja reči. Slažem se, dakako, s njim: „Izražavanje ne treba da bude što kraće, već - po meri misli koje se žele izraziti“ (str. 186). Ali je prethodno potrebno znati koje su to misli koje zaslužuju da se izraze u Nacrtu. Ono što je Nacrt izrazio i ono što bi Breneselović da izrazi nisu iste misli. Niti bi s njegovim mislima mogli nešto valjano obaviti u ovoj stvari.

\section{e. RETENCIJA}

19. VAŽNO JE ZVATI SE ZADRŽAVANJE. Breneselović ne mari za ustaljenu jezičku praksu. Predlaže da bude zamenjena izrazima kojima se, međutim, ništa ne dobija pošto su i ovi ustaljeni termini bar jednako tako razumljivi, u stvari i razumljiviji ako ni zbog čega drugog ono zbog poznatosti, a njihova upotreba, uostalom, ne stvara nikakve teškoće. Zato ni njegov okasneli kumovski predlog „Zadržaj“, ni njegov predlog „Zadržavanje“ (str. 195), nisu dobitak spram ustaljenog termina zadržanje (pravo zadržanja, član 522. Nacrta). A taj je termin u upotrebi bar od prevoda austrijskog AGZ (\$ 471), ${ }^{14}$ nalazi se kao isključivi izraz u Skici za Zakonik o obligacijama i ugovorima (član 233. i d.), ${ }^{15}$ a bilo kao jedini ili kao jedan od izraza i na drugim mesti-

13 „Službeni list SFRJ“, br. 6/1980, Zakon o izmenama i dopunama Zakona o osnovnim svojinsko-pravnim odnosima, „Službeni list SFRJ“, br. 36/1990 i Zakon o izmenama i dopunama Zakona o osnovnim svojinsko-pravnim odnosima, „Službeni list SRJ“, br. 29/1996.

14 Up. Dragoljub Aranđelović, Austrijski Građanski zakonik, Beograd 1906, str. 63.

15 Mihailo Konstantinović, Obligacije i ugovori (Skica za Zakonik o obligacijama i ugovorima), Beograd 1969, str. 77. i d. 
ma. ${ }^{16}$ Međutim, nepokolebljiv je Breneselović u tome da treba „zadržavanje, kako i stoji u Zakonu o obligacionim odnosima (čl. 286, 728)“ (str. 195). U žaru bitke za zadržavanje nije ga zadržao ni naslov tog, 728. člana Zakona o obligacionim odnosima, koji crno na belo, ne može biti jasnije, glasi: Pravo zadržanja, nego se neosnovano pozvao na njega kao da glasi Pravo zadržavanja. Opet se i tu Breneselović našao na suprotnom polu od onih njegovih „pažljivih“ i „najpažljivijih čitalaca“, koje (na str. 192, 193-194. i 205) priziva u pomoć protiv Nacrta.

20. NEOPHODNOST IZLIŠNOG (1). Prigovara što se u članu 522. Nacrta "govori o tome da 'poverilac ima pravo zadržanja stvari' umesto jednostavno da poverilac može ili ima pravo da stvar zadrži“ (str. 195).

Ali, pravo zadržanja i pravo da se stvar zadrži nisu isto. Pravo da se stvar zadrži samo je jedno od dva ovlašćenja koja zajedno tvore pravo zadržanja. Ono ne iscrpljuje pravo zadržanja, da bi se moglo samo reći da poverilac kao zadržalac ima pravo da stvar zadrži, budući da poverilac kao zadržalac ima i pravo da se namiri iz njene vrednosti, osim kada je propisano drugačije.

21. RAZVLAČENJE PO VERTIKALI. „... jedna rečenica se pojavljuje kao nosilac dve potpuno različite misli - prava na zadržavanje i prava na namirenje“, zamera Breneselović (na str. 195) odredbi člana 522.

Taj član opisuje sadržinu prava zadržanja, ovlašćenja iz kojih se ono sastoji, a ima ih dva. Da bi Breneselović došao na svoje (jedna misao - jedna rečenica), morao bi da razloži i razvuče, raspe sva složena stvarna prava u onoliko stavova jednog člana, koliko je ovlašćenja koja čine pravo o kome se radi. Originalno, ali čemu? Ko je to još radio? Da je primereno, valjda bi u višemilenijumskom regulisanju stvarnih prava takvo nešto već negde iskrslo.

22. NEOPHODNOST IZLIŠNOG (2). Član 522. govori o pravu zadržanja „stvari ili hartije od vrednosti“. Breneselović tvrdi (na str. 196): „Takvo udvajanje je problematično već sa stanovišta pravne dogmatike jer su i hartije od vrednosti stvari u smislu čl. 15 Nacrta. Nomotehnički je to udvajanje upadljivo jer svedoči o neprikladnom nomotehničkom programu u kome se sudiji i drugim licima ne poverava ni tako prosta analogija kakva bi bila shodna primena člana na hartije od vrednosti ili pak podjednaka primena na određena i odrediva potraživanja."

Hartije od vrednosti jesu, doduše, stvari, ali nisu kao druge stvari. Zbog svoje osobenosti (da sadrže prava u sebi) u mnogom pogledu podležu druga-

16 Na primer, Pravni leksikon, Beograd 1964, str. 314, 2. izd., 1970, str. 375, Radmilo Lorencin, Retencija, u: Enciklopedija imovinskog prava i prava udruženog rada, tom 2, Beograd 1978, str. 1272. i d., Pravna enciklopedija, Beograd 1979, str. 454, Pravna enciklopedija, tom 2, Beograd 1985, str. 527, izd. 1989, str. 527, Obren Stanković Miodrag Orlić, Stvarno pravo, Beograd 1996, str. 260. 
čijem pravnom režimu od ostalih stvari. Da li tako treba da bude i kod prava zadržanja, to pitanje je posve umesno, štaviše nezaobilazno. Pogotovo s obzirom na to što opštem režimu zadržanja ne podležu neke druge stvari, mada su i one, kao i hartije od vrednosti, takođe stvari, i mada ni one, kao ni hartije od vrednosti, nisu samo stvari (lične isprave). Na pitanje: opšti ili poseban režim za neke vrste stvari, može se dati više od jednog odgovora. Odgovor koji Breneselović naziva "tako prosta analogija kakva bi bila shodna primena člana na hartije od vrednosti“, nije ni jedini moguć, niti takav da će se nametnuti kao najbolji van svake razumne sumnje. U svakom slučaju, ne postoji nomotehničko pravilo da neizvesnost o nekom pravnom pitanju koju može sam da otkloni, zakonodavac treba da prevali na organe primene i onda kada on ima stav o tome koje je od mogućih rešenja najbolje. Postoji, baš naprotiv, suprotno pravilo. Pravne sigurnosti radi. Ne radi se, dakle, o nepoverenju tvoraca Nacrta spram sudova, koje im Breneselović imputira svojim konferencijskim rečnikom: „odsustvo poverenja“. (Uostalom, neumesno govori o analogiji, bila ona prosta, kao što se njemu čini, ili već kakva. Analogijom se popunjavaju pravne praznine. Ako bi odredba govorila uopšteno o zadržanju stvari, tada se na pitanje, da li ta odredba važi i za hartije od vrednosti kao jednu vrstu stvari, odgovara tumačenjem a ne popunjavanjem pravnih praznina, pa dakle ne ni bilo kakvom analogijom.) ${ }^{17}$

Neosnovane su, dakle, Breneselovićeve primedbe na član 522. Nacrta. Ali su posve primenjive na njegov sopstveni predlog (sa str. 184) za formulaciju člana 4. stav 1. Nacrta (kao prilog više zbirci onih piščevih primedaba koje se okreću protiv samog pisca, II.2). Služeći se baš njegovim rečima (sa str. 196. i d.), primedbe glase ovako: „nedostatak nomotehničkog programa koji indikuje“ njegova formulacija člana 4. stav 1 . „je posebno gravidan. On se sastoji iz ... udvajanja nosećih pojmova člana, te se tako" u njegovom članu 4. stav 1. „govori“ da zakonom određenu sadržinu stvarnih prava ne mogu izmeniti „državni i drugi organi [koji zakon primenjuju]'. Takvo udvajanje stvari je problematično već sa stanovišta pravne dogmatike jer su" i državni organi takođe organi primene zakona. „Nomotehnički je to udvajanje upadljivo jer svedoči o neprikladnom nomotehničkom programu u kome se sudiji i drugim licima ne poverava ni tako prosta analogija kakva bi bila ... podjednaka primena“ na državne i druge organe koji primenjuju zakon. „No i u odsustvu poverenja prema sudovima, takvo za oko i razum neprijatno udvajanje moralo je“ Breneseloviću „signalizirati da je zarad čitkosti neophodno da ... pribegne nekom drugom nomotehničkom triku, kakva je naznaka da shodno važi i“ za državne organe.

17 Umesto mnogih, v. Claus-Wilhelm Canaris, Die Feststellung von Lücken im Gesetz (Eine methodologische Studie über Voraussetzungen und Grenzen der richterlichen Rechtsfortbildung praeter legem), Berlin 1964, str. 22. i d. 


\section{f. STVARI}

23. STVAR KAO PLAVI ČUPERAK. Ne vidim opasnost da bi neko drugačije primenio normu koja kaže da je stvar „svaka materija“ koja ... (član 15. Nacrta), nego li normu koja kaže da je stvar „svaki deo materije“ koji ..., iako Breneselović ovu drugu smatra mnogo uspešnijom (str. 207). U obe formulacije radi se uostalom o pojavnim oblicima materije. Zvali ih materijama ili delovima materije, to su čvrsta tela, tečnosti, gasovi i dr. Kada se bilo „svaka materija“, bilo „svaki deo materije“ povežu sa drugim rečima iste rečenice („na kojoj se može imati faktička vlast i svojina ili drugo stvarno pravo“), oba izraza („svaka materija“ i „deo materije“) imaju isti smisao. Za razliku od toga, nisam već siguran kako bi se primenjivači snašli sa smislom „stvari“ iz Breneselovićevog predloga za pojam stvari: „Stvar u smislu ovog zakonika je svaki smisleni (opojmljeni, opredmećeni) deo materije“ (str. 207). Odredba sa takvom definicijom umesna je taman koliko i Breneselovićeva distinkcija da „U prirodi postoji samo materija, a stvari postoje u ljudskoj glavi“ (str. 207). Jezički deterministi (Wilhelm von Humboldt i dr.) kažu nam da ako za nešto nemamo reč (a sve su reči u ljudskoj glavi), o tome ne samo da ne možemo govoriti, nego ne možemo ni misliti. Sa materijom nije u tom pogledu ništa dugačije nego sa stvarima.

24. STATUS POLOŽAJA. Kod Breneselovića i stvari imaju status: „status zasebnih delova čovekovog tela i stvari koje su odvojene od čovekovog tela" (str. 192), odnosno imaju položaj: „(Pravni) Položaj životinja ili Položaj kućnih ljubimaca" (str. 194).

Ovo poslednje bih prihvatio da kojim slučajem vodimo raspravu o tome da li i životinje imaju prava. I da ih, zastupajući afirmativan stav o pravima životinja, smatram subjektima prava. Međutim, Nacrt ni u jednoj od brojnih odredaba posvećenih kućnim ljubimcima (čl. 18, 114, 173, 219, 439, 634, 655) te životinje ne tretira kao subjekte prava, već kao objekte prava - kao stvari. Istina, kao stvari sui generis, ali kao stvari. ${ }^{18} \mathrm{~A}$, znano je, da samo subjekti imaju u pravu status, srpski: položaj. Pravni objekti, pa ni stvari među njima - nemaju. Mada, istina, stvari nemaju status, niti položaj kao njegov pravni sinonim, one imaju, kao i svaka materija, položaj u prostoru svemira. Ali, na taj Breneselović ne misli, nego na to koje se pravne odredbe primenjuju a koje ne primenjuju na pravne odnose između pravnih subjekata povodom životinja. Što se u pravu ne zove i ne može zvati ni statusom ni položajem.

25. POTROŠNOST POTROŠNE STVARI. „Kako je uopšte moguće“, pita se Breneselović na vrhuncu čuđenja, „da se u stvarnom pravu pojavni oblik

18 Ni novelirane odredbe ABGB-a $(\$ 285 a)$, BGB-a $(\$ 90 a)$ i ZGB-a $(\$ 641 a)$, u kojima se kaže da životinje „nisu stvari“, ne znače da su prestale biti stvari, nego da se na njih ne primenjuje opšti pravni režim stvari kada je u suprotnosti sa pravilima o dobrobiti životinja. 
stvari određuje prema sadržaju ugovora ('namenjena aktom raspolaganja')? Držanje i trošenje su elementarne radnje i ne mogu se definisati drugim pojmovima“ (str. 207). Sve je ovo napisao povodom člana 27. Nacrta kojim je određeno da je potrošna stvar - stvar koja sasvim ili znatno izgubi vrednost prvom upotrebom za koju je namenjena aktom raspolaganja.

Ako znamo da postoje reči koje u pravu imaju drugačije značenje nego u kolokvijalnom ili inom govoru, kao i da se rečima u pravu značenje određuje u vezi sa situacijama u kojima su pravno važne, onda je samo pitanje čemu služi u stvarnom pravu kategorija potrošna stvar. Tada su neumesna začudna pitanja poput ovih: „Nije li i štangla obogaćenog uranijuma, toner za štampač ili baterija potrošna stvar? Šta je sa veknom hleba ili olovkom?“ (str. 207). U stvarnom pravu ne bavimo se opštim iskustvom: šta biva sa veknom hleba redovno. Nego se povodom konkretnog slučaja i konkretne vekne hleba bavimo pitanjem kakva su prava i obaveze strana moguće u konkretnom pravnom odnosu povodom konkretne stvari. A to zavisi upravo od one prve upotrebe te stvari na koju se odnosi konkretan akt raspolaganja njome. Isto to kaže i $\S$ 92. BGB, kojeg on tu citira, misleći neosnovno da to čini sebi u prilog, a da mu je pri tom promaklo da je i u tom paragrafu baš naglasak na nameni stvari -"u skladu sa namenom". Čineći kompliment piscima te odredbe BGB-a što su u "definiciji' prosto ponovili ono što je u pojmu potrošnosti već sadržano“ (str. 207), prećutao je da su u toj istoj rečenici istog paragrafa, u delu koji je izostavio, potrošnu stvar i potrošnost definisali disjunktivno još i posredstvom „otuđenja“. Doslovno: stvar „čija se upotreba, shodna nameni, sastoji u potrošnji ili u otuđenju“. Dakle, posredstvom nečega što nikako nije prosto „u pojmu potrošnosti već sadržano“. Ali, to kvari Breneselovićevu zamisao. Usput izlaže iskušenju svoju korektnost u pozivanju na izvore. Potrošnost nije u pravu neko apstraktno svojstvo stvari, zasnovano na univerzalnom ili prosečnom ili bilo kakvom drugom iskustvu o tome šta biva sa nekom vrstom stvari kada se ona upotrebljava. Potrošnost je, naprotiv, definisana, baš onako kako je u pravu važno s obzirom na pravni odnos koji se tiče raspolaganja stvari. Pa je, zato, hleb nekada potrošna stvar, a nekada nepotrošna. Jedno je ili je drugo, u zavisnosti od namene te konkretne stvari konkretnim aktom raspolaganja (koji, uzgred, ne mora biti ugovor, na šta ga Breneselović svodi). Stvar neke vrste (hleb, cipela itd.) nije po sebi ni potrošna ni nepotrošna, nego je takva u zavisnosti od volje onoga ili onih koji njome raspolažu - da li su joj namenili da se utroši prvom upotrebom na koju se odnosi taj akt, ili ne. Jer, od toga zavisi sastav pravnog odnosa. Ako je, primerice, stvar data u zalogu, u zakup, ili na poslugu, nije namenjena tome da se utroši, jer se stvar koja je založena mora vratiti kada dužnik izmiri obavezu zalogoprimcu, odnosno kada prestane pravo zakupa i posluge.

26. PLODONOSNO O PRIPLODU. Da su pisci Nacrta „loše upotrebljavali ... reči“, ilustruje ovako: u članu 26. Nacrta „reč priplod je mimo svake zabeležene upotrebe u našem jeziku definisana kao 'mladunče životinje'. 
Kod Obrena Stankovića priplod zbirno označava mladunce životinja, odnosno stočni porod, što opet nije isto što i jedan mladunac - priplodak." (str. 190-191). Kaže, takođe, da je u odrednici „priplod“ u Leksikonu građanskog prava, koja o priplodu govori u jednini, „pogrešno pročitan $₫ 261$ SGZ“ (str. 191. i prim. 9. na toj stranici).

Da je označavanje mladunaca životinja rečju priplod „mimo svake zabeležene upotrebe u našem jeziku“, tome ne daju za pravo ni udžbenici pisani na osnovu $\S$-a 261. SGZ, ${ }^{19}$ kao ni Stankovićev udžbenik, posredstvom kojeg su decenijama, iz godine u godinu brojni pravnici (doduše ne baš Breneselovićevi „milioni“) usvajali takvo značenje. I ne samo oni, ako se uzmu u obzir i neka druga dela (ne jemčim da su jedina). ${ }^{20}$ Kao i dela u kojima se priplod ne javlja samo kao množina, nego i u jednini. ${ }^{21}$ „Mimo svake zabeležene upotrebe u našem jeziku", tada nikako ne predstavlja odgovarajući opis učestalosti upotrebe reči priplod u takvom značenju i obliku. Pa "priplodak“ slobodno neka ostane in statu nascendi.

\section{g. U SMISLU ZAKONIKA, U SKLADU SA ZAKONOM, I ZAKONOM I PRAVNIM PORETKOM}

27. FANTOM NEDOSTAJUĆEG (2). Ne miri se sa time što u Nacrtu Zakonika na raznim „mestima nedostaje naznaka da je neki pojam određen samo za potrebe njegovih odredbi - 'u smislu zakonika',, (str. 207). Hvali zakonodavce u čijim odredbama je „pojam stvari ... izričito određen samo $z a$ potrebe zakona. Zakonodavci su tako rekli da su reč stvar upotrebili samo u jednom od njenih značenja i da su ljudima i pravnicima ostavili da i dalje govore o stvarima u raznim prilikama koje stvarno pravo ne uređuje" (str. 207).

Tvorci normi nemaju imperijalne namere kada nešto definišu u okviru određenog dela pravnog poretka. A i da imaju, ne bi im pomoglo, jer svaka pravna norma ima samo svoj domen primene. Kao što Krivični zakonik ima svoj pojam pokretne stvari koji se ne primenjuje u građanskom pravu, tako i

19 Vidi, na primer, Andra Đorđević, Sistem privatnog (građanskog) prava, Beograd 1893, str. 359, Živojin Perić, Specijalni deo Građanskoga prava, I, Stvarno pravo, Beograd 1922, str. 42. i d.

20 Vojislav Spaić, Građansko pravo, Opšti deo i Stvarno pravo, Sarajevo 1971, str. 616, Radmila Kovačević-Kuštrimović - Miroslav Lazić, Stvarno pravo, Niš 2006, str. 21, Zoran P. Rašović, Stvarno pravo, Beograd 2006, str. 32, isti, Komentar Zakona o osnovama svojinsko-pravnih odnosa, Podgorica, 1999, str. 118, Leksikon građanskog prava, Beograd 1966, str. 580, Obren Stanković, Stvari, u: Enciklopedija imovinskog prava i prava udruženog rada, tom 3, Beograd 1978, str. 174.

21 Pravni leksikon, Beograd 1964, str. 724, 2. izd., 1970, str. 902, Pravna enciklopedija, Beograd 1979, str. 1114, Pravna enciklopedija, tom 2, Beograd 1985, str. 1302, izd. 1989, str. 1302. 
stvarnopravni pojam pokretne stvari neće potisnuti krivičnopravni iz njegove primene na krivičnopravne slučajeve. Zakonik o svojini i drugim stvarnim pravima nije ni Akademijin ili koji drugi rečnik, niti Opšta ili koja druga pravna enciklopedija. Zakonik o stvarnim pravima bi imao domen svoje primene, kao i svaki drugi izvor prava, jer uređuje samo stvarnopravne odnose. On ne predstavlja čak ni Opšti deo Građanskog zakonika, da bi se moglo pomisliti da njegove odredbe pretenduju na to da važe - makar - u svim delovima građanskog prava ili bar u većini.

28. NEOPHODNOST IZLIŠNOG (3). Breneselović tvrdi (na str. 187) da izraz „u skladu sa zakonom“ u članu 9. stav 1. opterećuje rečenicu „potpuno izlišnim informacijama“. I u svojim predlozima izostavlja „u skladu sa zakonom“ $i$ ovome slične izraze.

Njemu je isto da li će u odredbi (člana 9. stav 1) stajati da se nešto ima smatrati da je tako, dok se suprotno ne dokaže u skladu sa zakonom, ili će je normativno obogaljiti pa da glasi: da će se smatrati da je tako, dok se suprotno ne dokaže. Ta, navodno potpuno izlišna informacija ima, međutim, i te kakav normativni značaj: znači da nešto ne sme da se odredi nižim pravnim aktom od zakona.

29. NEOPHODNOST IZLIŠNOG (4). Nalazi (na str. 198) da je u članu 79. Nacrta „neuobičajna naznaka da je postupanje vlasnika sa stvari ograničeno zakonom i pravnim poretkom; neuobičajna, jer su i zakoni deo pravnog poretka“.

Zakoni jesu deo pravnog poretka. Njihovo izričito navođenje uz pojam (pravni poredak) koji ih obuhvata moglo bi se pravdati klasičnom postavkom učenja o zakonodavstvu, da pravne odredbe valja da su jasne i laicima. „Pravni poredak“ je laicima manje prepoznatljiv nego „zakon“, koji, istina, jeste samo deo pravnog poretka, ali je, za razliku od ovog, pojam poznat nepravnicima. Štaviše, vrlo je verovatno da upravo on kod nepravnika stoji za celokupan pravni sistem. Glavni razlog udvajanja: zakon i pravni poredak, leži, međutim, drugde. Nije lako prevideti da Nacrt obe te reči upotrebljava govoreći o ograničenjima prava svojine („u granicama ..."). A, biće da je znano da se jedno pravo koje je zajemčeno Ustavom Republike Srbije (član 58) i ratifikovanim međunarodnim aktima - Prvim protokolom uz Evropsku konvenciju za zaštitu ljudskih prava (član 1), ne sme ograničavati pravnim aktima nižim od zakona (legalnost ograničenja kao uslov za dopuštenost ograničenja garantovanih prava - čl. 58, 18, 145, 194. Ustava, i konstantna sudska praksa Evropskog suda za ljudska prava u Strazburu). To se ne može iskazati samo rečju „pravni poredak“, baš zato što on obuhvata i akte više i akte niže od zakona, nego se zakon mora izričito navesti kao minimalno dopušteno ograničavajuće sredstvo. 


\section{h. TERMINOLOGIJA}

30. NEOČIGLEDNOST OČIGLEDNOG. „... ne treba upotrebljavati $h i-$ perbole, odnosno vrlo jake reči tamo gde im nikako nije mesto. Takva jedna hiperbola postoji kada se zahteva da mora da bude očigledno da će se nešto u budućnosti dogoditi, odnosno nešto što se u budućnosti može dogoditi: čl. 523 Nacrta. Ako je očigledno da dužnik o dospelosti neće biti sposoban za namirenje, zadržalac može vršiti pravo zadržanja i pre dospelosti“. Predlaže umesto toga formulaciju: „Izuzetno, poverilac može zadržati [dužnikovu] stvar i pre nego što je dužnikova obaveza dospela, ako postoji ozbiljna i za svakoga uočljiva opasnost da dužnik o dospelosti neće biti sposoban da potraživanje poverioca namiri“ (str. 185).

Svako će se složiti da ne samo hiperbole, vrlo jake reči, nego valjda ni bilo koje druge, ne treba upotrebljavati "tamo gde im nikako nije mesto“. Samo, da bi bilo ko ovde prosudio o umesnosti upotrebljene reči „očigledno“, prvo bi morao znati o kom se to mestu upotrebe radi, tj. na šta se ovde odnosi reč očigledno. Ne radi se, kako on misli, o nečemu što će se „u budućnosti dogoditi“ odnosno „što se u budućnosti može dogoditi“, već o tome šta se sada (a ne ubuduće) može sa dovoljnom sigurnošću znati o budućem razvoju događaja. „Očigledno“ nije prejaka reč za kakvu neizvesnu budućnost, već pravilo koje traži od primenjivača norme da utvrdi kako sada stvari stoje (na primer, da je dužnik sada insolventan). Osim toga, „očigledno“ iz Nacrta nije ništa jača reč od Breneselovićeve „ozbiljne i za svakoga uočljive opasnosti“. Kada je izraz „očigledno“ preveo kao „ozbiljnu i za svakoga uočljivu opasnost da dužnik o dospelosti neće biti sposoban da potraživanje poverioca namiri“, Breneselović možda nije ni imao u vidu kakva još tumačenja dopušta izraz očigledno: očigledno kao izvesnost, sigurnost da neće moći da izvrši obavezu, očigledno kao isključenost drugačije mogućnosti, očigledno kao neposrednost ili vremenska bliskost nemogućnosti izvršenja, očigledno kao nepotrebnost dokaza o nemogućnosti izvršenja, očigledno kao nalog za objektivnu procenu i isključenje mogućnosti da se ugrozi dužnikova pozicija. ${ }^{22} \mathrm{Da}$ su autori Nacrta hteli da se opredele za jedno od mogućih značenja, pa bilo to i ovo koje je izabrao Breneselović, to bi i učinili. Opredeljenje za neku materijalnopravnu koncepciju očiglednosti iziskuje u svakom slučaju složenije argumentacione strukture nego što su argumenti samo na osnovu jezičke analize.

31. ISTO DRUKČIJE ILI DRUKČIJE DRUKČIJE? Kao konstruisanje na silu deluje primedba (sa str. 189) da se u članu 10. Nacrta reč „drukčije“ na jednom mestu može pročitati i kao prilog i kao imenica, a na drugom da je prilog. „Drukčije“ se - valjda ćemo se o tome složiti - doista krajnje retko

22 Upućujem na raznovrsna tumačenja sudske prakse i teorije u pogledu izraza „očigledno" u vezi sa \$-om 1295. st. 2. ABGB i drugim izvorima, v. V. V. Vodinelić, Takozvana zloupotreba prava, Beograd 1997, str. 7. i d. 
nalazi u imeničkom značenju. Ni na ovom mestu ne oseća se kao imenica. Razlike između „drukčije“ iz tog člana u prvoj upotrebi i u drugoj upotrebi naprosto - nema. Oba puta je, bez obzira na red reči, ta reč prilog, koja se u prvoj upotrebi samo prividela kao moguća imenica. A ne bi ni to, da se Breneselović, tako ponet jezičkom stranom stvari, makar upitao za smisao pravila sadržanog u tom članu. - U preuveličavanja spada i ovo: „... neophodno je“ u članu 10. stavu 2. Nacrta „preobličiti sekvensu 'odredbe ovog zakonika o stvarnim pravima'“, „jer činjenica da se Zakonik zove Zakonik o svojini i drugim stvarnim pravima podsvesno signalizira citaocu da je to i smisao pomenute sekvense iako nije“. Umesto toga valja reći: „Odredbe o stvarnim pravima koje sadrži ovaj zakonik“ (str. 189). Nepoželjno delovanje na podsvest doista je nešto od čega štiti čak i pravo (setimo se, recimo, zabrane subliminalnih reklama). Ali, Zakonik se zove Zakonik o svojini $i$ drugim stvarnim pravima, pa je nesumnjivo da je i svojina jedno od stvarnih prava, a ne nešto van njih. Da bi se svojina odelila od stvarnih prava, za to bi bio potreban (uzaludan) napor baš na nivou jasne - $\mathrm{i}$ to pravničke - svesti. - Istog roda je i insistiranje na tome da "Po ugovoru ipak nije isto što i na osnovu ugovora" (str. 193), te da u članu 11. stav 2. Nacrta tim drugim valja zameniti prvo. Pravnici, ali i nepravnici, i te kako u takvom kontekstu kažu „po“, ne praveći pri tome baš nikakvu razliku prema „na osnovu“. Zar se ne kaže ravnopravno: po zakonu njegova prava su ..., kao i: na osnovu zakona njegova prava su ... A ni sa „po osnovu“ nije drugačije od „na osnovu“: stekao je pravo po tom osnovu, i stekao je pravo na tom osnovu. (Uostalom, u Nacrtu je redovan oblik „na“, dok se „po“ sreće tu i tamo.)

32. KOKOŠKA ILI JAJE? Tvrdi da se u celom Nacrtu naziv svakog pravnog instituta izvodi iz naziva subjektivnog prava, iako je to subjektivno pravo samo sastojak tog pravnog instituta. „Takva šema se ponavlja kroz čitav Nacrt: svojina - pravo svojine, službenost - pravo službenosti, ručna zaloga - pravo ručne zaloge" (str. 196). Toga ima u Nacrtu. Netačno je, međutim, da je tako u celom Nacrtu. Recimo: Naslov Dela III, koji označava naslov instituta, glasi Svojina, a naslov Glave A. Dela III, koja se glava odnosi na subjektivno pravo, glasi Pravo svojine. Naslov Dela VI glasi Službenosti, a naslov Glave A. Dela VI je Prava službenosti. Naslov Dela VIII glasi Realni teret, a naslov Glave A. Pravo realnog tereta. Naslov Dela IX glasi Zaloga, a naslov Glave A. Prava zaloge. Naslov Dela X glasi Realni dug, a naslov Glave A. Pravo realnog duga. Ni u jednom od tih slučajeva, pridružujući im i Deo II, o državini i pritežanju, nije onako kako se u kritici olako tvrdi.

33. ESTETIKA PIJETETA. Breneselović misli da neko misli, a svakako autori Nacrta, kako je pravo na pijetet - pravo umrlih. Kao i da su autori Nacrta to i izrekli u njemu. Piše: „U čl. 17 čitamo kako se stvarna prava na lešu i delovima ljudskog tela ne mogu 'vršiti radi dobiti, protivno shvatanjima prometa, moralu i pravu na pijetet'. Pošto je pijetet ružna reč, a mrtvi ljudi 
ne mogu biti nosioci prava i obaveza, bilo je bolje reći da se stvarna prava na lešu, odnosno delovima tela ne smeju 'vršiti' protivno (obavezujućim) obzirima zajednice prema mrtvima ili protivno obzirima zajednice prema mrtvima koje svako mora da poštuje“ (str. 209).

Istina je da prava ličnosti nisu samo najneizgrađeniji deo našeg građanskog prava i građanskopravne književnosti. Nego su i najnerazvijeniji deo pravničkog obrazovanja. Ipak, nije baš da neko ko bi da štogod prozbori o ličnom pravu na pijetet, $\mathrm{k}$ tome još i kritički, ne bi mogao da se obavesti, čak i u domaćoj pravnoj književnosti, o tom pravu. ${ }^{23}$ Koje je pravo, naravno - pravo živih, pravo onih koji su bili bliski umrlome. Bar da se obavestio elementarno, koliko da zna makar toliko šta je posredi. Njegovo otkriće da „mrtvi ljudi ne mogu biti nosioci prava“ ravno bi bilo „otkriću“ da, pošto umrli ne mogu da izjave volju, onda ni pravni poslovi mortis causa ne postoje. A što se tiče lepote i ružnoće reči pijetet, „lasno“ mu bilo da o tome sudi.

34. ROK OD JEDNE GODINE KAO KOST U PRAVNIČKOM GRLU. „Pažljivom čitaocu posebno će zasmetati neobično i pogrešno povezivanje reči u frazoidne konstrukcije. Tako u čl. 114 I stoji rok od jedne godine. Na našem jeziku, osim izuzetno, kaže se rok od godinu dana... Do sada se o tome uglavnom dovoljno vodilo računa, - na primer u Zakonu o parničnom postupku (čl. 93 IV, 95 II, 247 II, 414; 392 IV, 413, 494), u Zakonu o vanparničnom postupku (čl. 57 I, 116; 204, 222), u Ustavu (čl. 203 IV; 172 VII)“ (str. 192). Tako i toliko od Breneselovića.

Ni do poslednje tačke svoga teksta nije odao tajnu o tome kada je to ono „osim izuzetno“ kada se sme ne reći „rok od godinu dana“. Ostaće skriveno i kojim je to aršinom izmerio da se kod nas „do sada“ „uglavnom dovoljno vodilo računa" o tome da se kaže godinu dana a ne jedna godina. Varljiva je pretpostavka da je empirijski utvrdio takvu jezičku praksu, kada je tek ovlaš ilustruje putem tri navedena propisa. Ali, avaj. U Zakonu o obligacionim odnosima, ${ }^{24}$ hvaljenom inače iz drugih razloga (str. 197), rok od jedne godine javlja se bar na osam mesta (član 117. stav 1, član 139. stav 2, član 233, član 285. stav 1, član 378. stav 1 , član 500. stav 1, član 507, član 885. stav 2). A provera u vidu štihprobe, od koje sam odustao već kod zakona na (četvrto po redu) slovo d, pokazuje da je rok od jedne godine (dopustiću sebi da kažem - osim izuzetno) odomaćen: član 48. stav 1. tačka 1, član 55. stav 1. Zakona o advokaturi, ${ }^{25}$ član 17. stav 3, član 26. stav 7, član 39, član 137. stav 1. tač. 8. i 18. Zakona o bankama, ${ }^{26}$ član 20. stav 3. Zakona o crkvama i verskim

23 Vidi V. V. Vodinelić, Lična prava, u: Enciklopedija imovinskog prava i prava udruženog rada, tom 1, Beograd 1978, str. 715. i d.

24 „Službeni list SFRJ“, br. 29/1978, 39/1985, 45/1989, 57/1989, „Službeni list SRJ“, br. 31/1993, „Službeni list SCG“, br. 1/03.

25 „Službeni glasnik SRJ“, br. 24/1998, „Službeni list SCG“, br. 1/03.

26 „Službeni glasnik RS“, br. 107/05. 
zajednicama, ${ }^{27}$ član 15. stav 2, član 195. stav 2. Zakona o državnom premeru i katastru. ${ }^{28}$ A nije baš tako ni izuzetno da oba izraza kohabitiraju u jednom te istom propisu.

35. PISMO I „PISMO“. Ne podržava da se u članu 608. kaže: „pismo“ realnog duga. Jer da je „u nemačkom pravničkom jeziku to ... bio značajni terminus technicus, a u našem nije" (str. 209). Kao da kreditno pismo, (bankarsko) akreditivno pismo, (bankarsko) pismo o namerama, koji kod nas odavna postoje, nisu nimalo razdvojili "pismo“ u pravu od koverte sa poštanskom markom.

36. STARO VINO, SAMO U NOVIM BOCAMA, ILI VIŠE OD TOGA? Neki su Breneselovićevi novopredloženi termini neodgovarajući, jer su još neodređeniji od u Nacrtu upotrebljenih, koji su makar već ustaljeni, a nije zabeleženo da su problematični, o čemu takođe nije vodio računa. „Uslužnost", biti odnosno naći se drugome na usluzi, ne može zato u članu 522. Nacrta valjano da se zameni „obzirom“, kao ni „prosta uslužnost“ - „čistim“ ili „golim obzirom“ (str. 209). Uz to, obzir već odavna u stvarnom pravu ima čvrsto mesto, sa drugačijim značenjem od onoga koje bi ovde trebalo da dobije: obzirno (civiliter) vršenje prava službenosti i dr. Niti može ono što je „u skladu sa shvatanjima prometa“ (čl. 17. i 24) biti odmenjeno „shvatanjima pravnog života“ (str. 209). I pravnici bi se zamislili nad time šta bi "pravo“ značilo u izrazu: shvatanja „pravnog“ života. Učesnici u pravnom životu su i državni organi i drugi organi koji primenjuju pravo, a na njihova shvatanje se uopšte i ne misli, nego samo na shvatanja onih koji su učesnici u prometu. A kada u primeni člana 24. valja da odrede da li je neka stvar pripadak druge, pravnici bi se još i više zamislili nad tim šta „pravni život“ ima sa tim da li je u običnom životu uobičajeno da jedna stvar služi drugoj stvari (na primer, šta pravni život ima sa tim da li se neka kofa upotrebljava u vezi sa nekim bunarom, pumpa - u vezi sa nekim biciklom, futrola - u vezi sa nekim naočarima, miš - u vezi sa nekim računarom).

37. FILOZOFIJA UŽITKA ILI: KUPOHOLIČARI I SLADOKUSCI U STVARNOM PRAVU. Reči koje se u pravu naširoko upotrebljavaju neretko imaju svoja značenja koja odstupaju od onih u kolokvijalnom govoru i drugde van prava. Kada Breneselović piše kao da to ne zna, rezultat toga su ipak najneobičnije primedbe $u$ celom njegovom sastavu. A iz njih na nekim mestima niču onda i izdanci koji svojom pojavom mogu i dodatno da uvesele. Evo, čujmo samog autora kako se baš zamislio nad jednim etabliranim pravnim izrazom sa etabliranim značenjem - „troškovi učinjeni radi zadovoljstva“: „u čl. 195 se govori o naknadi troškova učinjenih radi zadovoljstva, iako ... svakako nije suština u tome da je držalac trošio radi zadovoljstva, već je njegovo zado-

27 „Službeni glasnik RS“, br. 36/06.

28 „Službeni glasnik RS“, br. 18/10. 
voljstvo iziskivalo trošenje“ (str. 192). Kada bih se povodom ovog izraza i sam mogao praviti nepravnikom i ozbiljno uzeti ovo razmatranje o zadovoljstvu, apsolvirao bih temu podsetivši na to da je veza između troška i zadovoljstva dvostrana. Jer je zadovoljstvo moguće naći i u trošenju samom. Koga neće razgaliti finale u vidu ovakvog njegovog predloga za poboljšanje zakonskog jezika u članu 195. Nacrta: „Savesni držalac ima pravo na naknadu sredstava koje je u stvar za svoj [slatki] užitak uložio [...]“. Šta ovo bi - kakav slatki užitak? Da li je šala posredi, ili smo doista pročitali ove konditorske reči? 